Prepared in cooperation with the Bureau of Reclamation

\title{
Statistical Relations of Salt and Selenium Loads to Geospatial Characteristics of Corresponding Subbasins of the Colorado and Gunnison Rivers in Colorado
}

Scientific Investigations Report 2012-5003 



\section{Statistical Relations of Salt and Selenium Loads to Geospatial Characteristics of Corresponding Subbasins of the Colorado and Gunnison Rivers in Colorado}

By Kenneth J. Leib, Joshua I. Linard, and Cory A. Williams

Prepared in cooperation with the Bureau of Reclamation

Scientific Investigations Report 2012-5003 


\title{
U.S. Department of the Interior \\ KEN SALAZAR, Secretary \\ U.S. Geological Survey \\ Marcia K. McNutt, Director
}

\author{
U.S. Geological Survey, Reston, Virginia: 2012
}

For more information on the USGS - the Federal source for science about the Earth, its natural and living resources, natural hazards, and the environment, visit http://www.usgs.gov or call 1-888-ASK-USGS.

For an overview of USGS information products, including maps, imagery, and publications, visit http://www.usgs.gov/pubprod

To order this and other USGS information products, visit http://store.usgs.gov

Any use of trade, product, or firm names is for descriptive purposes only and does not imply endorsement by the U.S. Government.

Although this report is in the public domain, permission must be secured from the individual copyright owners to reproduce any copyrighted materials contained within this report.

Suggested citation:

Leib, K.J., Linard, J.I., and Williams, C.A., 2012, Statistical relations of salt and selenium loads to geospatial characteristics of corresponding subbasins of the Colorado and Gunnison Rivers in Colorado: U.S. Geological Survey Scientific Investigations Report 2012-5003, 31 p. 


\section{Contents}

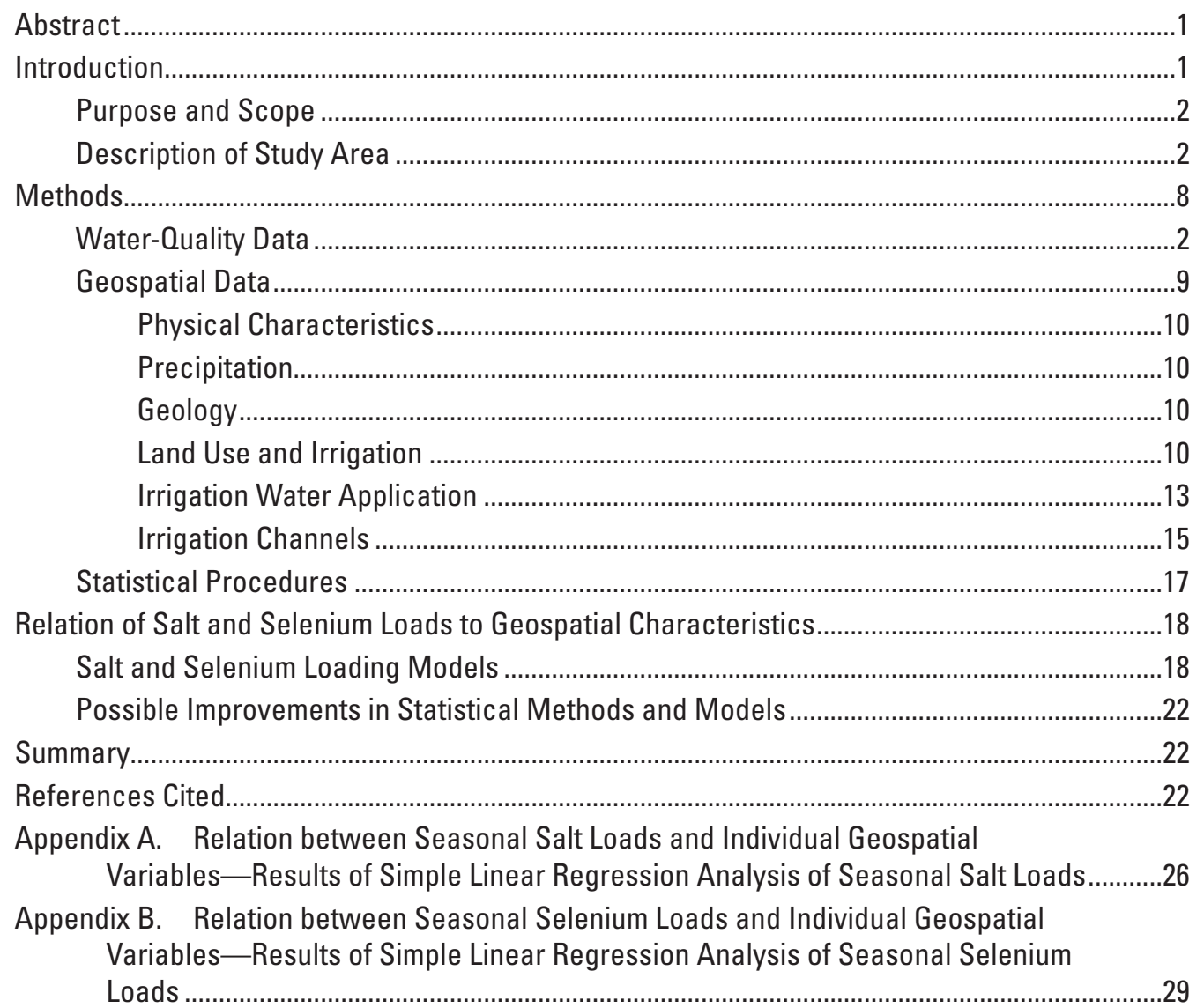

\section{Figures}

1. Map of lower Gunnison River study area showing stream gages at the study area boundary and climate stations used in this study.

2. Map of elevation, locations of sample sites used in the statistical correlations, and corresponding subbasins delineated within the lower Gunnison River study area..........4

3. Map of mean precipitation in lower Gunnison River study area during irrigation season nonirrigation season .....................................................................................

4. Map of outcrop area of Mancos Shale in lower Gunnison River study area ....................7

5. Diagram of relation of frost-free days to elevation at climate stations in lower Gunnison River study area.....

6. Diagram of relation of mean effective precipitation to mean precipitation at nine climate stations in and near lower Gunnison River study area

7. Map of estimated irrigation water applied in the lower Gunnison River study area ......16

8. Diagram of relation of channel wetted perimeter to channel capacity in lower Gunnison River study area

9. Diagrams of relation of mean measured loads to model estimated loads during irrigation- and nonirrigation-season salt load and irrigation- and nonirrigation-season selenium load. 


\section{Tables}

1. Geologic units within the lower Gunnison River study area and groups of units (subgroups) used in statistical correlations...................................................................11

2. Statistical values of seasonal salt and selenium load-prediction models.......................19

\section{Abbreviations Used in This Report}

$\begin{array}{ll}\text { DEM } & \text { digital elevation model } \\ \text { GIS } & \text { geographic information system } \\ \text { NHD } & \text { National Hydrography Dataset } \\ \text { NWIS } & \text { National Water Information System } \\ \text { USGS } & \text { U.S. Geological Survey } \\ & \\ \text { acre-ft } & \text { acre-feet } \\ \mathrm{ft} & \text { foot, feet } \\ \mathrm{ft}^{3} / \mathrm{s} & \text { cubic feet per second } \\ \text { in. } & \text { inch } \\ \mathrm{lb} / \mathrm{d} & \text { pounds per day } \\ \mathrm{mi}{ }^{2} & \text { square mile } \\ \text { ton/d } & \text { tons per day }\end{array}$




\section{Conversion Factors}

Inch/Pound to SI

\begin{tabular}{lcl}
\hline \multicolumn{1}{c}{ Multiply } & By & \multicolumn{1}{c}{ To obtain } \\
\hline inch (in.) & Length & \\
foot (ft) & 2.54 & centimeter $(\mathrm{cm})$ \\
& 0.3048 & meter $(\mathrm{m})$ \\
\hline acre & Area & \\
square mile $\left(\mathrm{mi}^{2}\right)$ & 4,047 & square meter $\left(\mathrm{m}^{2}\right)$ \\
\hline & 2.590 & square kilometer $\left(\mathrm{km}^{2}\right)$ \\
\hline acre-foot $($ acre- $\mathrm{ft})$ & Volume & \\
\hline & 1,233 & cubic meter $\left(\mathrm{m}^{3}\right)$ \\
\hline cubic foot per second $(\mathrm{ft} / \mathrm{s})$ & Flow rate & \\
\hline & 0.02832 & cubic meter per second $\left(\mathrm{m}^{3} / \mathrm{s}\right)$ \\
\hline ton per day $($ ton $/ \mathrm{d})$ & Mass & \\
pounds per day $(\mathrm{lb} / \mathrm{d})$ & 0.9072 & metric tons per day \\
\hline
\end{tabular}

Vertical coordinate information is referenced to the North American Vertical Datum of 1988 (NAVD 88).

Horizontal coordinate information is referenced to the North American Datum of 1983 (NAD 83).

Elevation, as used in this report, refers to distance above the vertical datum.

Specific conductance is given in microsiemens per centimeter at 25 degrees Celsius $(\mu \mathrm{S} / \mathrm{cm}$ at $\left.25^{\circ} \mathrm{C}\right)$.

Concentrations of chemical constituents in water are given either in milligrams per liter (mg/L) or micrograms per liter ( $\mu \mathrm{g} / \mathrm{L})$. 



\title{
Statistical Relations of Salt and Selenium Loads to Geospatial Characteristics of Corresponding Subbasins of the Colorado and Gunnison Rivers in Colorado
}

\author{
By Kenneth J. Leib, Joshua I. Linard, and Cory A. Williams
}

\section{Abstract}

Elevated loads of salt and selenium can impair the quality of water for both anthropogenic and natural uses. Understanding the environmental processes controlling how salt and selenium are introduced to streams is critical to managing and mitigating the effects of elevated loads. Dominant relations between salt and selenium loads and environmental characteristics can be established by using geospatial data. The U.S. Geological Survey, in cooperation with the Bureau of Reclamation, investigated statistical relations between seasonal salt or selenium loads emanating from the Upper Colorado River Basin and geospatial data. Salt and selenium loads measured during the irrigation and nonirrigation seasons were related to geospatial variables for 168 subbasins within the Gunnison and Colorado River Basins. These geospatial variables represented subbasin characteristics of the physical environment, precipitation, geology, land use, and the irrigation network. All subbasin variables with units of area had statistically significant relations with load. The few variables that were not in units of area but were statistically significant helped to identify types of geospatial data that might influence salt and selenium loading. Following a stepwise approach, combinations of these statistically significant variables were used to develop multiple linear regression models. The models can be used to help prioritize areas where salt and selenium control projects might be most effective.

\section{Introduction}

Elevated loads of salt and selenium can impair the quality of water for anthropogenic and natural uses. Large amounts of salt in water systems can clog and destroy municipal and household pipes and fixtures (Butler and von Guerard, 1996). The Bureau of Reclamation (2009) reports that high concentrations of salt make it difficult to grow winter vegetables and popular fruits. To prevent lower crop yields resulting from reduced plant uptake of highly saline water, plants need to be irrigated excessively (Jenke, 1974; Butler and von Guerard,
1996; U.S. Department of Agriculture, 1997). The cost of repairing damage caused by high concentrations of salt in the United States' portion of the Colorado River Basin ranges between $\$ 500$ million and $\$ 750$ million per year and could exceed $\$ 1.5$ billion per year if future increases in salt load are not controlled (Bureau of Reclamation, 2009). The potential impairments to biological resources from selenium loads have been a concern since 1985 (Butler and Leib, 2002). Selenium toxicity, resulting from rapid bioaccumulation of that trace element, is of particular concern for endangered fish species such as the Colorado pikeminnow, razorback sucker, bonytail chub, and humpback chub, and for other aquatic organisms (See and others, 1992; Hamilton, 1998, 1999; Lemly, 2002; Leib, 2008). Selenium toxicity has been shown to cause reproductive deformities and failure (Gates and others, 2009).

Understanding the environmental processes by which salt and selenium are introduced into streams is critical to managing and mitigating the effects of their elevated loads. The term "salt" in this report refers to the mass of all cations and anions in an aqueous solution and is expressed in terms of load, which has units of ton per day (ton/d). Selenium is a naturally occurring trace element and can be expressed in terms of load with units of pounds per day $(\mathrm{lb} / \mathrm{d})$. The principal processes by which salt and selenium are introduced into the hydrologic environment are the dissolution of salts from porous media and the oxidation and mobilization of selenium from porous media by groundwater. Different types of bedrock can produce different amounts of salt and selenium. In particular, Cretaceous marine shales of the western United States readily contribute high concentrations of salt and selenium to groundwater (Seiler and others, 1999). In turn, groundwater can directly contribute to streamflow and, as a result, increase the amount of salt and selenium in streams. Salt and selenium loads in streams draining the Upper Colorado River Basin of western Colorado, where Cretaceous marine shales are prevalent, are higher than in streams that drain other areas in the southwestern United States (Anning and others, 2006).

The amount of salt and selenium in groundwater is related to the geochemical environment, the amount of water available to interact with bedrock, and the surficial area of bedrock material exposed to water. Salt will readily dissolve 
Salt and Selenium Loads and Geospatial Characteristics in Subbasins of Colorado and Gunnison Rivers, Colo.

into groundwater, whereas selenium requires an aqueous oxidizing environment to enter into groundwater (Butler and others, 1996). Percolating water, from precipitation or irrigation, generally has more oxygen than underlying groundwater. As this oxygen-rich meteoric or applied irrigation water moves through the subsurface, it mobilizes salt and selenium. In most natural areas not subject to human influence, the amount of water available to interact with bedrock is limited by the amount of precipitation that the area receives. Percolating irrigation water increases the amount of water available to interact with bedrock and can increase the altitude of the water table, which in turn can increase the surface area of bedrock available to interact with water.

Irrigation in areas of the Upper Colorado River Basin of Colorado has become prevalent as land cover has been converted from native vegetation to agricultural crops. Irrigation water is brought to the area through a network of irrigation channels (canals and ditches) and is applied to the crops by one of several methods, which include flood and sprinkler irrigation. Percolation of water from unlined sections of the irrigation network and from water applied to fields (in excess of that consumed by crops) typically causes a rise in water-table altitude. The introduction of oxygenated water, the subsequent rise in the water table, and the prevalence of Cretaceous marine shales together provide an ideal environment in which salt and selenium can enter into groundwater flowing to streams (Butler, 1996; Butler and others, 1996). The effect of irrigation is seasonal, as previous studies have illustrated, and corresponds with seasonal salt and selenium loads in streams (Butler, 2001).

Irrigation also can increase the amount of salt and selenium in groundwater and in surface runoff through its role in the development of efflorescent salt crusts. Infiltrating water dissolves salt and selenium from near-surface soils as it moves downward through the soil profile (Hedlund, 1994). The volume of irrigation water commonly exceeds the needs of the agricultural crop, and some of the excess water evaporates. As soil water evaporates, efflorescent salts precipitate onto the soil surface (Laronne, 1977). Surface runoff produced by subsequent precipitation or excess irrigation can dissolve the salt crusts or entrain sediments to which the salt is adsorbed (Johnson and Schumm, 1982).

The complex subsurface and surface processes controlling salt and selenium loading of streams make it difficult for land managers to control these constituents. In order to limit salt transport to streams within the Upper Colorado River Basin, the Colorado River Basin Salinity Control Program was formed in 1974. As part of this program, the Bureau of Reclamation and the U.S. Department of Agriculture Natural Resources Conservation Service have spearheaded salt-control efforts within the area. The primary control projects promote the lining of irrigation channels, laterals, and ponds and help farmers establish more efficient irrigation practices, such as drip, sprinkler, or surge irrigation systems (Butler, 1996). However, identification of the areas that would benefit most from a control project is difficult because it is unclear which characteristics of the environment (such as geology, irrigation network density, irrigation application method, or the altitude of the water table) are most responsible for high loads of salt and selenium. In order to better understand the relations between characteristics of the environment and salt and selenium loads, the U.S. Geological Survey (USGS), in cooperation with the Bureau of Reclamation, investigated statistical relations between salt and selenium loads emanating from the Upper Colorado River Basin and corresponding geospatial characteristics.

\section{Purpose and Scope}

The purpose of this report is to present statistical relations between water-quality data pertaining to salt and selenium loads and geospatial data. The relations were developed by using data for 168 subbasins within the Gunnison and Colorado River Basins. A detailed description of methods used to select, process, and analyze water-quality and geospatial data are presented. Statistical relations between salt and selenium loads and geospatial variables were evaluated for irrigation and nonirrigation seasons. Geospatial variables that were found to be significantly related to salt and selenium loads were used to develop multiple-linear regression models of mean seasonal salt and selenium loads at the subbasin outflow sites.

\section{Description of Study Area}

The part of the Upper Colorado River Basin discussed in this report, herein referred to as the lower Gunnison River study area, consists of the Gunnison River Basin downstream from the stream gage below the Gunnison Tunnel (09128000) and the part of the Colorado River Basin from downstream from the stream gage near Cameo, Colo. (09095500), to the stream gage at the Utah-Colorado state line (09163500) (fig. 1). The study area contains 5,899 square miles $\left(\mathrm{mi}^{2}\right)$, of which $3,963 \mathrm{mi}^{2}$ drain directly to the Gunnison River. Elevation ranges from about 14,153 feet in the headwaters of the Uncompahgre River to about 4,333 feet at the Utah-Colorado state line (fig. 2). The study area is considered to have an arid climate, and for the period 1961 through 1990 the average annual precipitation was 19.3 inches (in.) (Daly and others, 1994). Areal distributions of the mean annual precipitation during the irrigation season (April-October) and the nonirrigation season (November-March) for the period 1961-1990 are shown in figure 3 . Historically, agriculture has been common in near-stream areas, and during the period analyzed in this study, it occupied about 7.3 percent of the study area (TechniGraphicS, Inc., 2004). A dense network of irrigation channels provides water to growers within the basin, facilitating the conversion of areas of natural vegetation to agriculture (fig. 1). On the basis of results of this study, the amount of applied irrigation water can vary considerably within a subbasin depending on the irrigation method and can be as much as $60 \mathrm{in}$.

annually. Soils in near-stream areas and agricultural fields are dominantly derived from Mancos Shale, which is a Cretaceous marine shale occupying $1,090 \mathrm{mi}^{2}$, or 18.5 percent of the study area (fig. 4) (Day and others, 1999). 


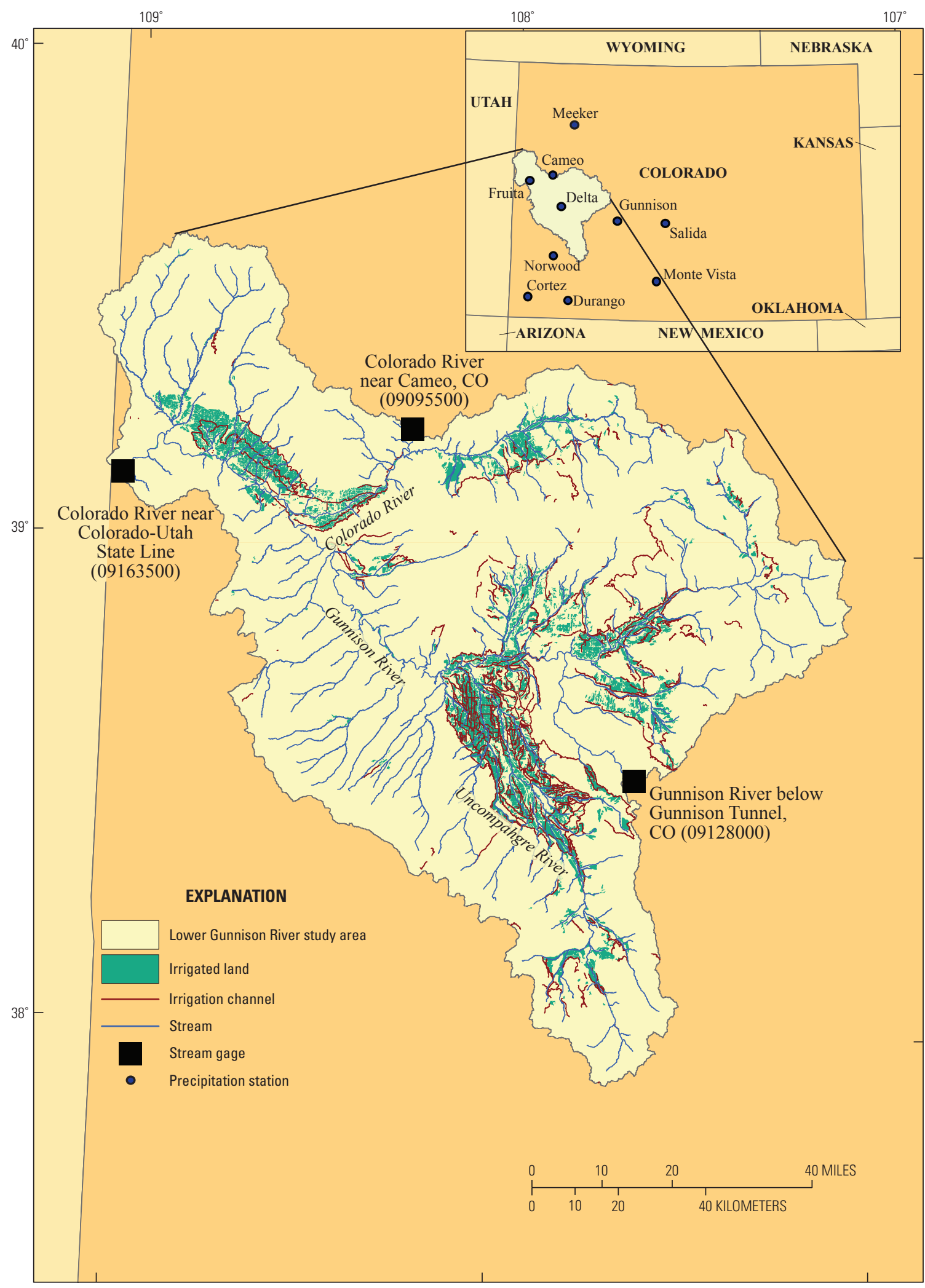

Figure 1. The lower Gunnison River study area showing stream gages at the study area boundary and precipitation stations used in the study. 


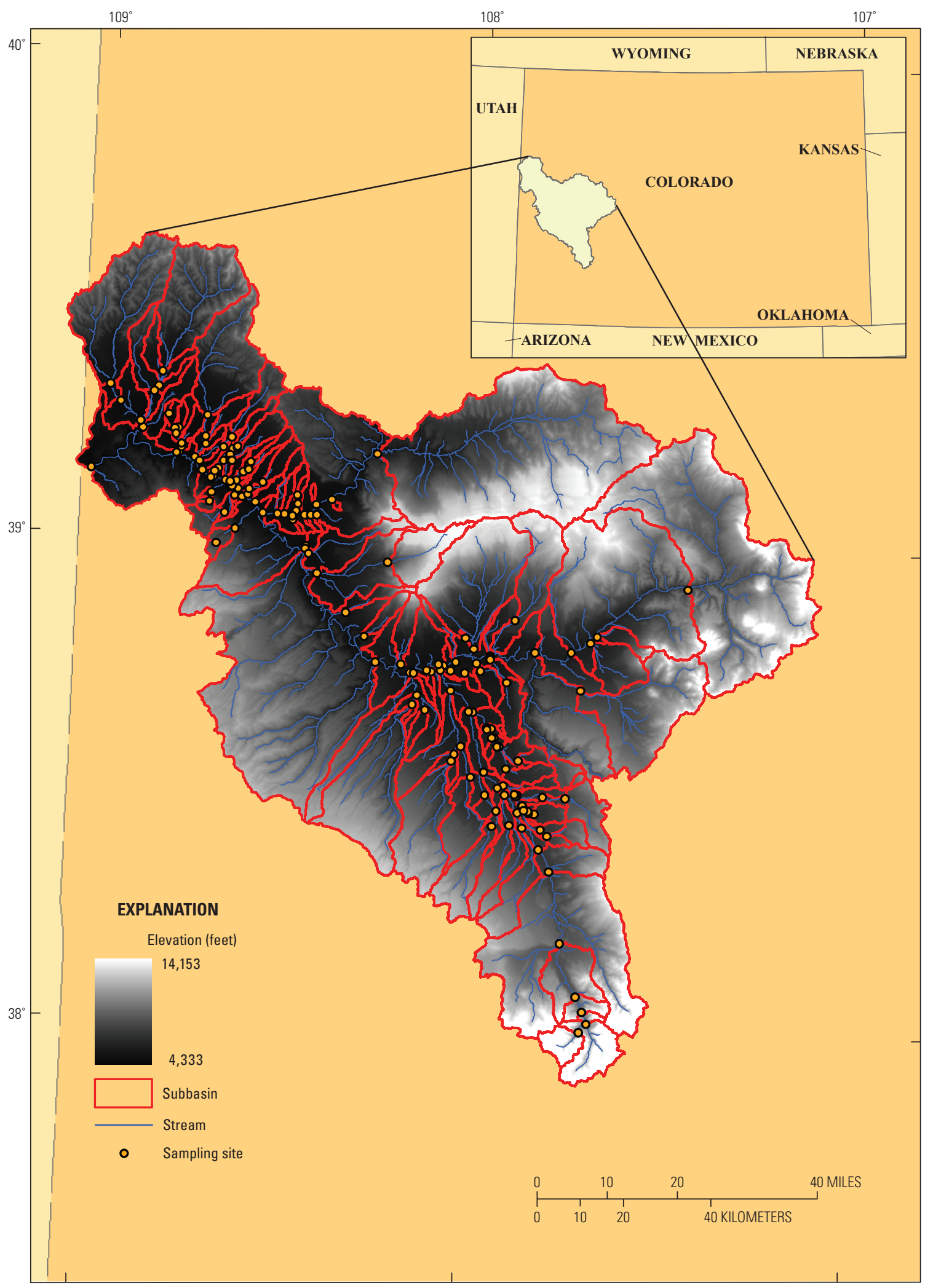

Figure 2. Elevation, locations of sample sites used in the statistical correlations, and corresponding subbasins delineated within the lower Gunnison River study area. 


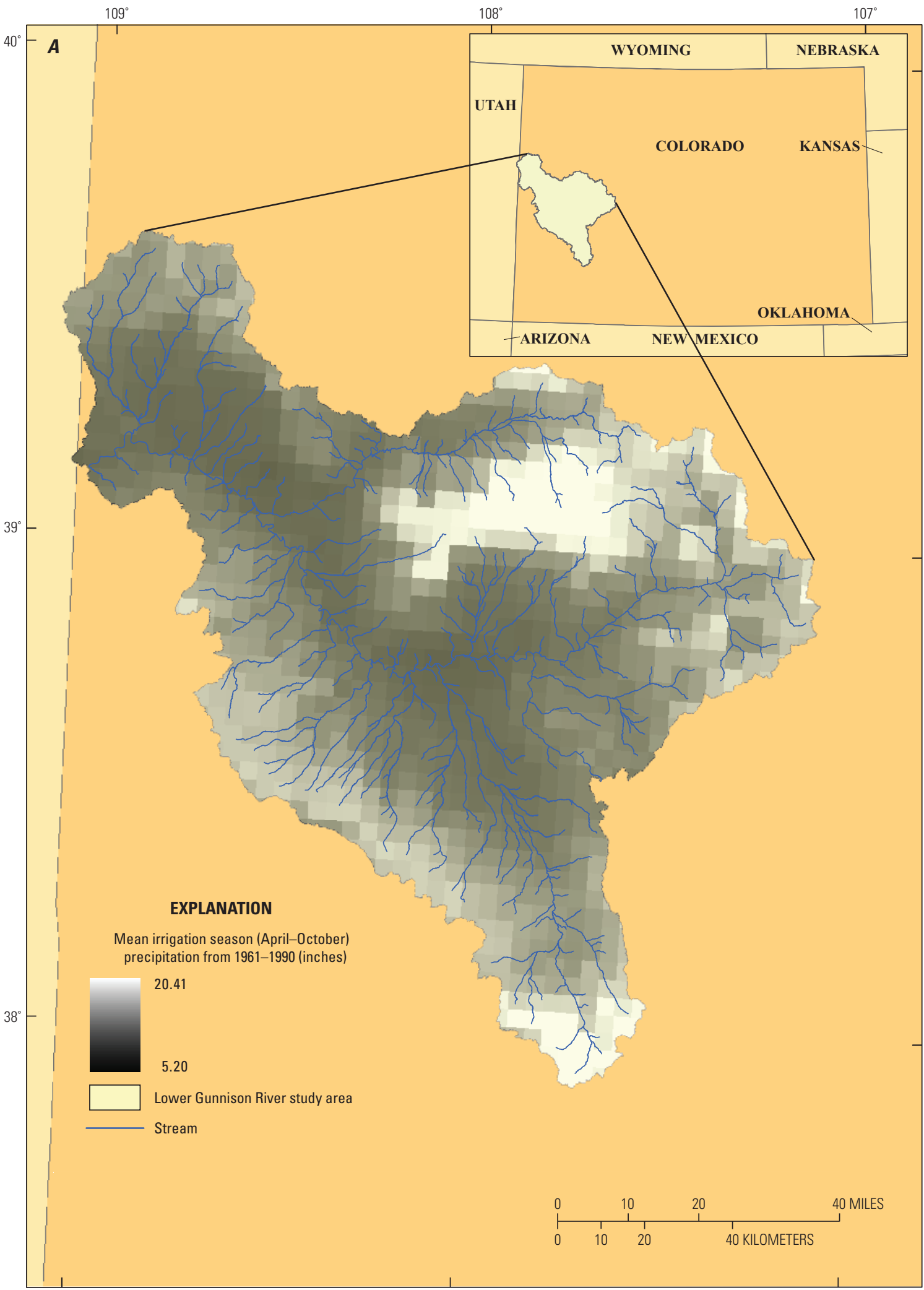

Precipitaion data from Daly and others, 1994.

Figure 3. Mean precipitation in the lower Gunnison River study area during $(A)$ irrigation season (April through October) and $(B)$ nonirrigation season (November through March). 


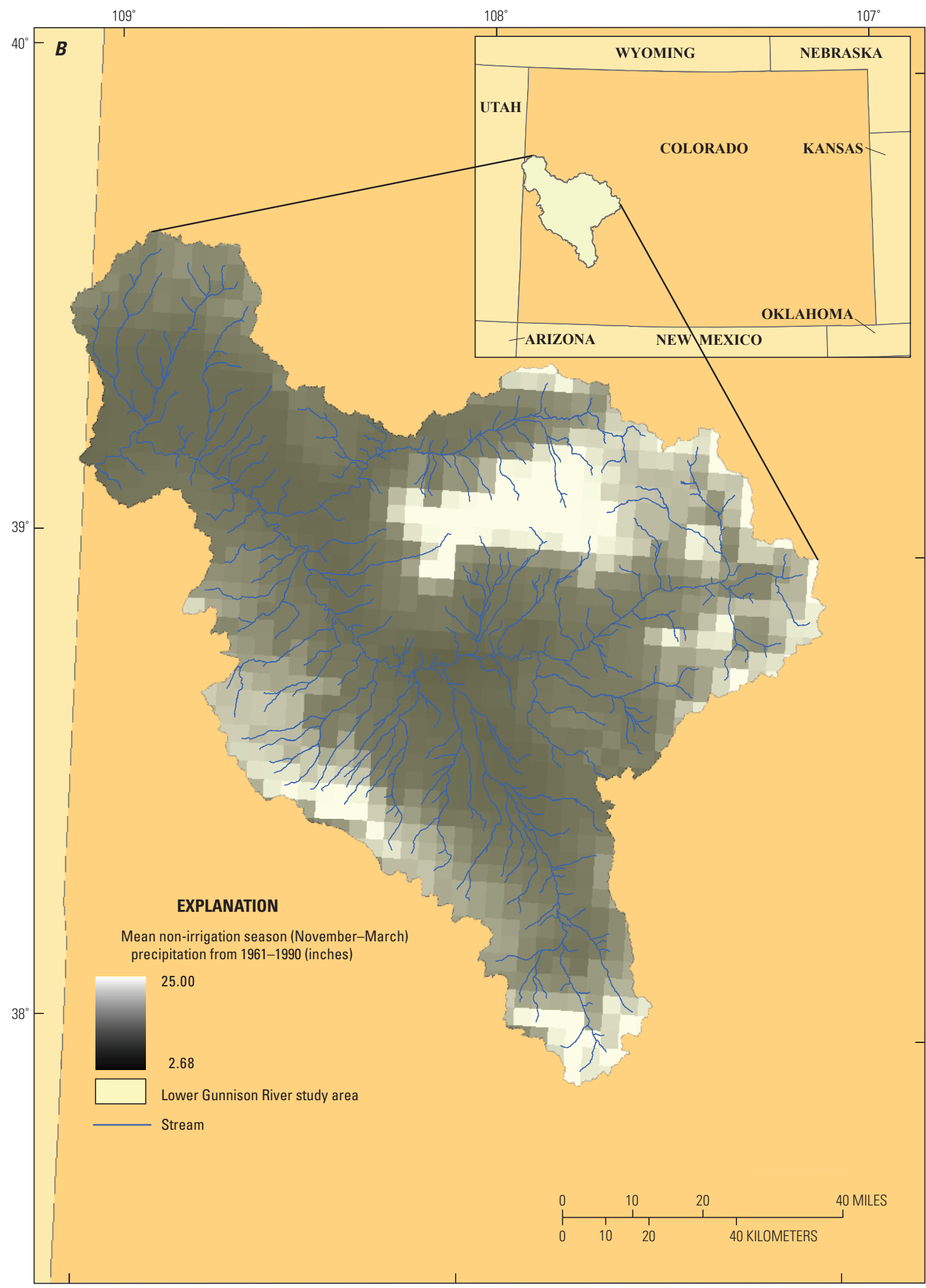

Precipitaion data from Daly and others, 1994.

Figure 3. - Continued Mean precipitation in the lower Gunnison River study area during $(A)$ irrigation season (April through October) and (B) nonirrigation season (November through March). 


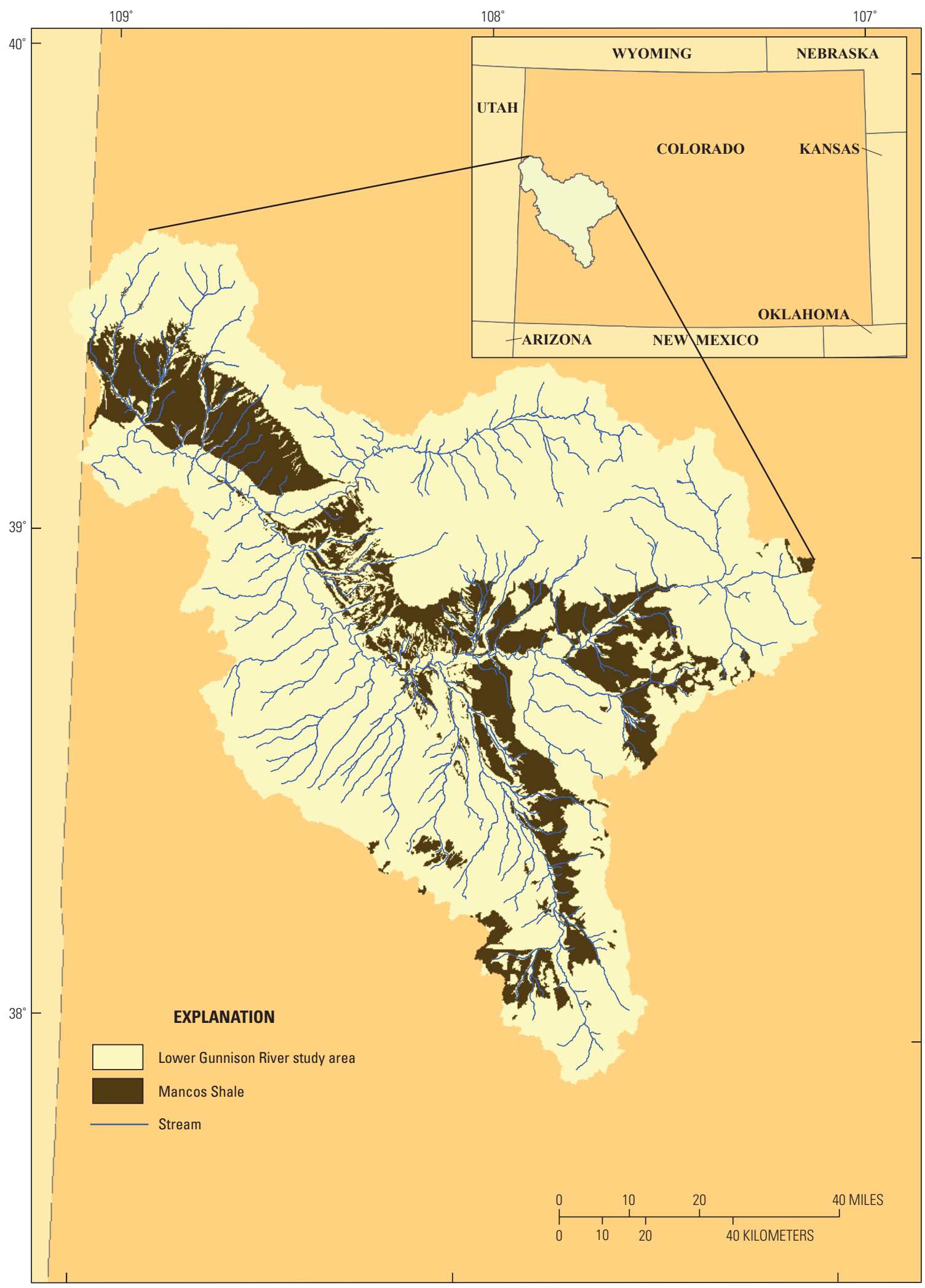

Figure 4. Outcrop area of geologic units in the lower Gunnison River study area designated as Mancos Shale. 
Salt and Selenium Loads and Geospatial Characteristics in Subbasins of Colorado and Gunnison Rivers, Colo.

\section{Methods}

Water-quality data and geospatial data were obtained from publicly available databases. Statistical relations were evaluated by using the compiled data. The types of water-quality data and geospatial data and the statistical procedures used to analyze these data are described in the following sections.

\section{Water-Quality Data}

The water-quality data used in this study were obtained from previous USGS studies and data-collection efforts and pertained primarily to in-stream salt and selenium loads. All data used were derived from water-quality samples that were collected by using standard USGS protocols. Samples were analyzed by using methods described by Fishman and Friedman (1989). Concentrations of dissolved-solids (salt) and of selenium concentrations along with streamflow at the time of sampling were retrieved from the USGS National Water Information System (U.S. Geological Survey, 1998). These data were used to compute constituent loads, defined as the mass of material flowing past a sampling site during a specific time interval. Salt load is expressed in units of tons per day (ton/d) and selenium load in units of pounds per day $(\mathrm{lb} / \mathrm{d})$. Instantaneous loads were calculated from the retrieved water-sample data by multiplying the streamflow (cubic feet per second), the constituent concentration (milligrams or micrograms per liter), and a units-conversion factor. The initial dataset was composed of all USGS salt and selenium data available for the study area; it contained data for 2,998 samples from 231 sample sites. These sites were located on natural streams and on irrigation channels. The number of samples for each site ranged from 1 to 424 . Although the periods of record for individual sites differed, the data set encompassed 15 water years, from 1990 through 2004.

Previous assessments of the water-quality data indicated distinct differences in water chemistry during irrigation and nonirrigation seasons (Butler, 1996, 2001; Butler and others, 1996; Butler and Leib, 2002). Loads were higher during the irrigation season because more water was available to mobilize salt and selenium from porous media and transport these constituents to streams. Therefore, in the current study, loads calculated from the water-quality data were separated into irrigation and nonirrigation seasons. The lengths of the seasons were based on the time during which irrigation water is applied to crops. The irrigation season consisted of the 7-month period from April 1 through October 31, and the nonirrigation season was from November 1 through March 31 . Mean seasonal loads at each sampling site were determined by averaging all the instantaneous loads available for each season during 1990-2004. Streamflow and water quality can be highly variable through time, so these mean seasonal loads probably are not accurate for any specific year; however, for the purposes of this report they are considered adequate to account for major differences among sites.

Each sampling site on a natural stream in the original dataset was used to define an upstream drainage area, or "subbasin." All tributary subbasins were entirely within the study area; however, the headwaters of the Gunnison and Colorado River main-stem subbasins were outside the study area. For these subbasins, the mean seasonal load at the most upstream site on the main-stem river was subtracted from the loads at all downstream sites in order to determine the net load originating within the study area. For example, the most upstream sampling site on the Gunnison River within the study area is below the Gunnison Tunnel (gage 09128000). Mean loads at this site were $546 \mathrm{ton} / \mathrm{d}$ for salt and $1.28 \mathrm{lb} / \mathrm{d}$ for selenium during the irrigation season (April-October) and 426 ton/d for salt and $0.55 \mathrm{lb} / \mathrm{d}$ for selenium during the nonirrigation season (November-March). These loads were subtracted from the mean seasonal loads calculated for downstream sites on the Gunnison River and on the Colorado River downstream from its confluence with the Gunnison. Similarly, mean seasonal loads at the most upstream site on the Colorado River (near Cameo, Colo., gage 09095500) were 4,290 ton/d for salt and $14.5 \mathrm{lb} / \mathrm{d}$ for selenium during the irrigation season and 3,050 ton/d for salt and $8.82 \mathrm{lb} / \mathrm{d}$ for selenium during the nonirrigation season. These loads were subtracted from the mean seasonal loads calculated for downstream sites on the Colorado River. The resultant mean seasonal loads at these downstream sites could then be attributed to mobilization and transport of salt and selenium within the study area.

Subbasin mean seasonal loads also were adjusted to account for gains and losses of salt and selenium through the irrigation network. A subbasin could gain from irrigation channels if the sum of channel loads leaving the subbasin was less than the sum of channel loads entering the subbasin. Conversely, a subbasin could lose to irrigation channels if the sum of channel loads leaving the subbasin was greater than the sum of channel loads entering the subbasin. Owing to a lack of data accounting for the spatial variability of the hydrologic processes occurring within and between subbasins, characterizing gains or losses in load by irrigation channels for individual subbasins was difficult. In this study, mean annual salt and selenium loads were calculated for all water-quality sampling sites on channels in the irrigation network. The net annual load attributable to the irrigation network within a specific subbasin was calculated as the sum of loads at irrigation-channel inflow sites $\left(B_{I}\right)$ minus the sum of loads at irrigation-channel outflow sites $\left(B_{O}\right)$. Samples were collected only during May and August at these irrigation-network sites. To avoid discrepancies between loads calculated at these sites and loads at the subbasin outlet, a factor $v$ was defined to adjust the net channel load to the maximum percentage attributable to the irrigation network, estimated as the quotient between maximum daily load and the irrigation season mean-daily load: 


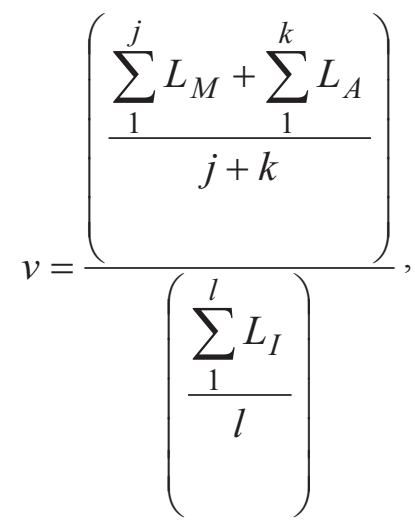

where $L_{M}$ is a load measured at an irrigation channel site during the month of May, $j$ is the number of water-quality samples collected in May, $L_{A}$ is a load measured at an irrigation channel site in August, $k$ is the number of water-quality samples collected in August, $L_{I}$ is a load measured during the irrigation season at the subbasin outlet, and $l$ is the number of water-quality samples collected during the irrigation season. The net mean-annual load $\left(L_{b}\right)$ attributable to the irrigation network within any specific subbasin was calculated as:

$$
L_{b}=\left(\sum B_{I}-\sum B_{O}\right) \cdot v .
$$

This mean-annual load was then apportioned between the irrigation and nonirrigation seasons. Although salt and selenium loads from the irrigation network occur during irrigation season (April-October), the channels can flow during the nonirrigation season to support livestock. The fraction of $L_{b}$ that occurred in the nonirrigation season was defined as $Z$, the quotient between mean-daily loads for the nonirrigation season and mean-daily loads for the irrigation season. The meandaily load during the irrigation season was assumed to be the maximum load supplied by irrigation-network water. Loads observed during the nonirrigation season were assumed to represent a part of the maximum contribution. Adjusted irrigation $\left(L_{\text {Iadj }}\right)$ and nonirrigation $\left(L_{\text {NIadj }}\right)$ seasonal loads at the subbasin outlet were calculated by using the following equations:

$$
\begin{gathered}
L_{\text {Iadj }}=L_{I}+L_{b} \cdot(1-Z), \\
L_{\text {NIadj }}=L_{N I}+L_{b} \cdot Z,
\end{gathered}
$$

where $L_{I}$ and $L_{N I}$ are the mean seasonal loads calculated by using data collected at the subbasin-outlet site. Seasonal loads at seven subbasin outlets were adjusted. Accounting for load brought into a subbasin by the irrigation network resulted in negative adjustments; the load originating within the subbasin was less than the total load observed at the outlet. Accounting for load leaving a subbasin by the irrigation network resulted in positive adjustments. The mean percentage difference between the initial subbasin salt loads and the adjusted salt loads was -116 percent for the nonirrigation season and -27 percent for the irrigation season. The mean percentage difference between the initial subbasin selenium loads and the adjusted selenium loads was -278 percent for the nonirrigation season and -22 percent for the irrigation season. Adjustments were positive at two sites and increased average load about 5 percent.

Some sites in the original dataset provided data of limited value to the study and were not used. These included sites with poorly defined drainage areas, such as irrigation network sample sites and sample sites where the measured streamflow consisted solely of water diverted directly from the irrigation network to the stream channel. Defining a subbasin for these sample sites was difficult because of the limited data available to describe the irrigation channels, which have numerous inflows and outflows and traverse along contours and thus cross topographical boundaries. As a result, an irrigation channel can originate in one subbasin (not necessarily confined to the study area) and terminate in another.

In the final dataset, the number of subbasins with data adequate to evaluate loads differed by constituent and season. Data from 78 subbasins were used to evaluate the relations between salt loads and geospatial variables during the irrigation season. Data from 146 sites were used to evaluate the relations between salt loads and geospatial variables during the nonirrigation season. Data from 82 sample sites were used to evaluate the relations between selenium loads and geospatial variables during the irrigation season. Data from 154 samples sites were used to evaluate the relations between selenium loads and geospatial variables during the nonirrigation season.

\section{Geospatial Data}

The geospatial data used in this study pertained to physical characteristics, precipitation, geology, land use, irrigation practices, and irrigation channel networks. A geographic information system (GIS) was used to aid in organizing, viewing, and manipulating the geospatial data. The GIS was used for terrain processing (for example, Viger and Leavesley, 2007), to delineate subbasin boundaries, and to evaluate geospatial variables for each individual subbasin.

Subbasin boundaries were delineated by using landsurface elevation data. Setting accurate boundaries was required in order to determine the spatial extent of the topographic area contributing salt and selenium loads at the sample sites. A digital elevation model (DEM) obtained from the USGS National Elevation Dataset (U.S. Geological Survey, 1999a) was used to define the geographic extent of 168 subbasins (fig. 2). The outlet of each subbasin was determined on the basis of water-quality sample site locations provided by the NWIS database (U.S. Geological Survey, 1998) and stream networks defined by the USGS National Hydrography Dataset (NHD) (U.S. Geological Survey, 1999b). 
Manual adjustment of sample-site locations was necessary. Although streams and sample sites would be expected to exist at topographic lows, commonly the National Elevation Dataset, NHD, and NWIS data did not coincide spatially. The NHD was used as the base to which topographic information and sample-site coordinates were forced to conform. The DEM was conditioned within the GIS by using the NHD and methods consistent with Ries and Dillow (2006). Generally, this conditioning identified elevation values from the DEM that coincided with the NHD stream network and decreased them by a specified amount such that those elevations were forced to be topographic lows. From the resulting DEM, a stream network was delineated and the locations of sample sites were manually adjusted to ensure that their locations coincided with the stream network. Following this conditioning, subbasins were delineated upstream from each sample site. The area of the 168 subbasins ranged from 0.26 to $5,899 \mathrm{mi}^{2}$. The subbasins delineated for each sample site were used as a basis for extracting geospatial variables from larger geospatial datasets of the entire study area.

\section{Physical Characteristics}

The physical characteristics of subbasins, which were based on elevation (mean, minimum, maximum, and change) and area, were extracted from the same DEM used to define the subbasins. These physical characteristics can interact with other characteristics to influence the availability, mobilization, and transport of salt and selenium to streams. Higher elevations can receive greater amounts and different types of precipitation (such as rain or snow) than lower elevations. These characteristics can affect how much and where water might be available to transport salt and selenium. The time of year at which snowmelt contributes to percolation or runoff can be a function of the subbasin's aspect. The hillslopes of subbasins whose streams drain south receive more solar radiation than those facing north and, consequently, snow in south-facing subbasins melts earlier and more quickly (Singh and Singh, 2001). These differences in timing of snowmelt and depletion of snow cover can influence the amount of water available for percolation. Basin slope influences runoff timing, infiltration, and groundwater gradients (Polubarinova-Kochina, 1962). Larger subbasins have more area from which to derive loads and thus have the potential to produce greater loads than smaller subbasins.

\section{Precipitation}

The amount of precipitation in a subbasin can affect the amount of salt and selenium mobilized and transported to streams. Precipitation in the lower Gunnison River study area increases with elevation and varies spatially as a result of dynamic wind forces and land-surface configuration (figs. 2 and 3). These spatial patterns can be made apparent by using data estimated by the precipitation-elevation regressions on independent slopes model (PRISM) (Daly and others, 1994).
For this study, mean-monthly data generated by this model were used to generate maps of mean seasonal precipitation (irrigation and nonirrigation seasons) for the study area. The spatial distribution of precipitation was similar in the two seasons (fig. 3). During the irrigation season, precipitation ranged from 5.20 to 20.41 in.; during the nonirrigation season, it ranged from 2.68 to $25.00 \mathrm{in}$. The mean precipitation received by each subbasin in each season was calculated from these maps by use of the GIS.

\section{Geology}

The geologic age, lithology, and geochemistry of rock units in each subbasin can affect the physical availability (abundance and ease of mobilization) of salt and selenium within the subbasin. Certain rock units, such as Cretaceous marine shales in the Western United States, contain abundant salt and selenium (Seiler and others, 1999). Within a given subbasin, the erosional expression of a particular geologic unit is the net result of its resistance to the local forces of weathering and erosion acting. Different units in the sequence of geologic formations can have distinctively different erosional forms within the study area, such as the steep, narrow valleys along parts of the Gunnison River and the wide, flat valleys of the Colorado River. These differences influence the interactions and transport of available salt and selenium within shallow alluvial aquifers in this study area.

To define the spatial distribution and abundance of potential salt and selenium sources, digital geologic maps of Utah (Hintze and others, 2000) and the Gunnison, Grand Mesa, and Uncompahgre National Forests (Day and others, 1999) were combined into a single dataset. Known correlations and anecdotal correlations described by Butler and others (1996) concerning geochemical and physical properties were used to categorize geologic units into 3 groups and 34 subgroups (table 1). For example, a subgroup of geologic units (such as subgroup 1.10 in table 1) was created by combining geospatial data for various units of the Mancos Shale (fig. 4). The percentage of total subbasin area was determined for each geologic subgroup shown in table 1.

\section{Land Use and Irrigation}

Numerous investigations have shown that land use influences salt and selenium loads (Butler and von Guerard, 1996; U.S. Department of Agriculture, 1997; Bureau of Reclamation, 2009). As vegetation removes water from the soil, it limits the amount of water available to percolate into and interact with bedrock. Different types of vegetation use different amounts of water through the growing season and thus use available water at different rates. The impermeable surfaces typical of residential, industrial, or transportation land uses decrease infiltration. Some of this decrease may be offset by infiltration associated with unlined irrigation ponds and storm catchments, which collect and retain water before it can reach a stream (Mayo, 2008). 
Table 1. Geologic units within the lower Gunnison River study area and groups of units (subgroups) used in statistical correlations.

[Fm, Formation; Ma, mega-annum (millions of years ago); <, less than; Rock unit symbol, map unit symbols used in reference maps (Hintze and others, 2000; Day and others, 1999); Groups 1,2, and 3 indicate which rock units were grouped geospatially and correlated to water-quality data]

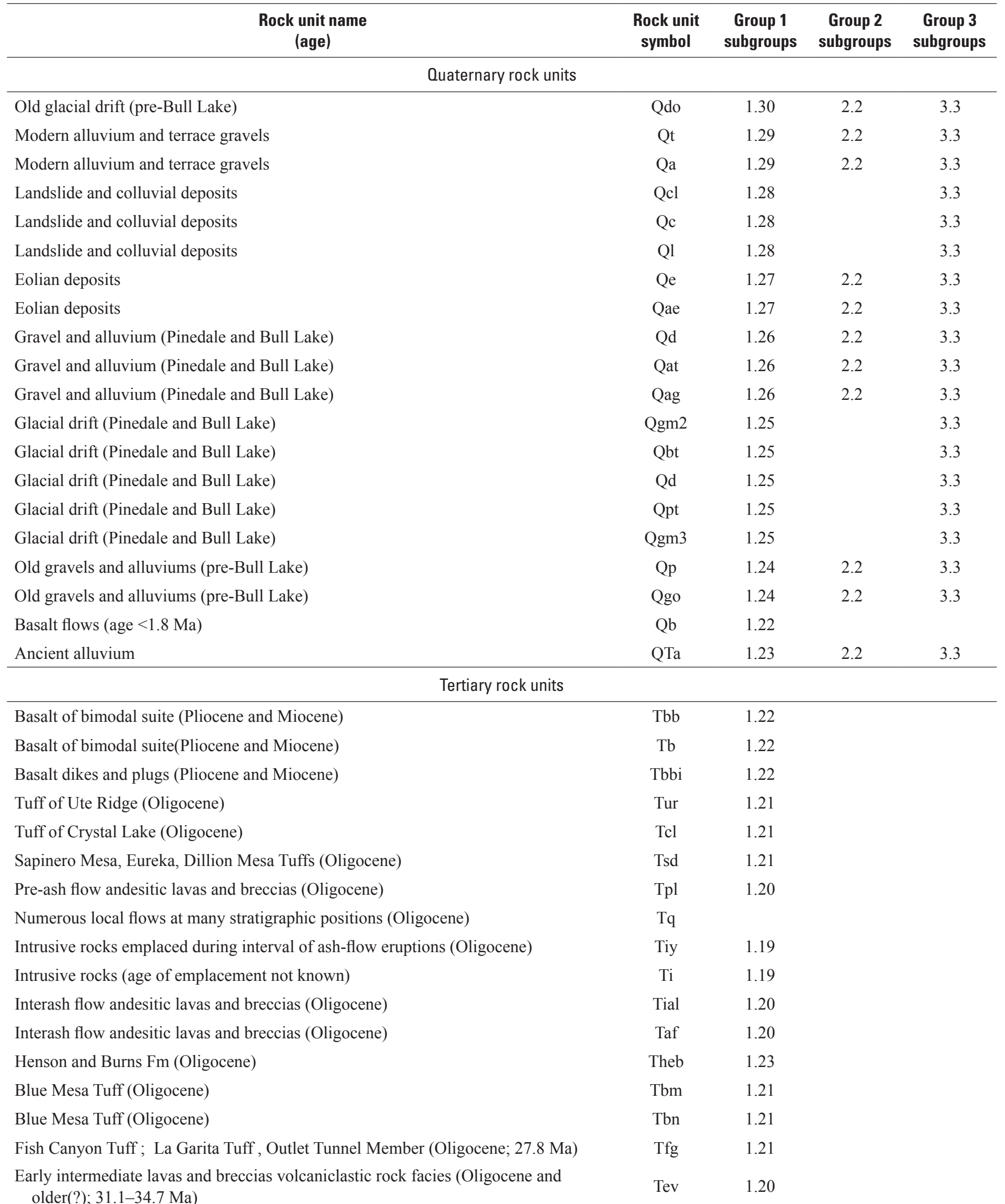




\section{Salt and Selenium Loads and Geospatial Characteristics in Subbasins of Colorado and Gunnison Rivers, Colo.}

Table 1. Geologic units within the lower Gunnison River study area and groups of units (subgroups) used in statistical correlations.Continued

[Fm, Formation; Ma, mega-annum (millions of years ago); <, less than; Rock unit symbol, map unit symbols used in reference maps (Hintze and others, 2000; Day and others, 1999); Groups 1, 2, and 3 indicate which rock units were grouped geospatially and correlated to water-quality data]

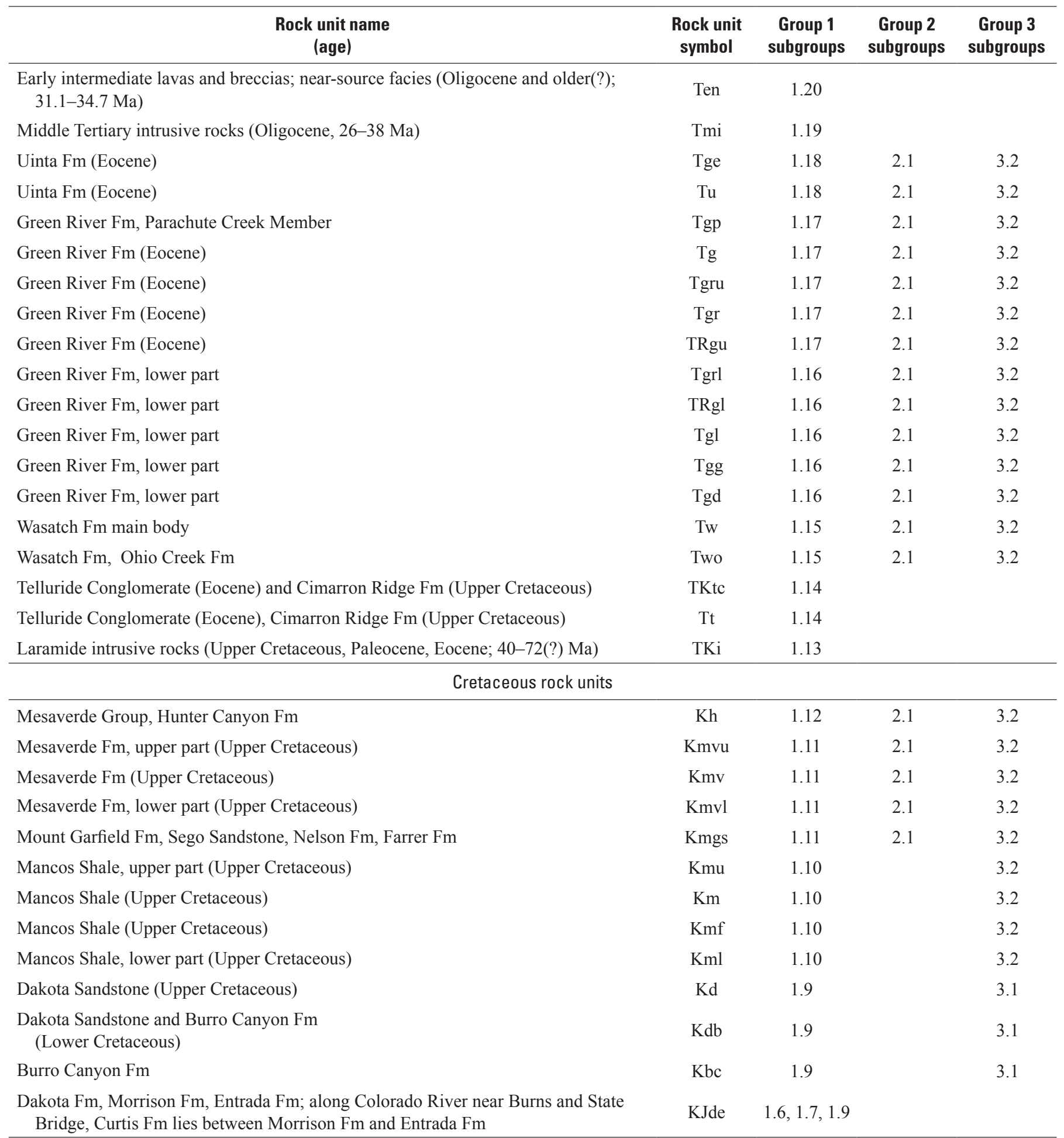

Jurassic rock units

\begin{tabular}{lrr}
\hline Morrison Fm (Upper Jurassic) & $\mathrm{Jm}$ & 1.7 \\
Morrison Fm (Brushy Basin Shale Member) & $\mathrm{Jmb}$ & 1.7 \\
Morrison Fm (Salt Wash Sandstone Member) & $\mathrm{Jms}$ & 1.7
\end{tabular}


Table 1. Geologic units within the lower Gunnison River study area and groups of units (subgroups) used in statistical correlations.Continued

[Fm, Formation; Ma, mega-annum (millions of years ago); <, less than; Rock unit symbol, map unit symbols used in reference maps (Hintze and others, 2000; Day and others, 1999); Groups 1,2, and 3 indicate which rock units were grouped geospatially and correlated to water-quality data]

\begin{tabular}{|c|c|c|c|c|}
\hline $\begin{array}{l}\text { Rock unit name } \\
\text { (age) }\end{array}$ & $\begin{array}{l}\text { Rock unit } \\
\text { symbol }\end{array}$ & $\begin{array}{c}\text { Group } 1 \\
\text { subgroups }\end{array}$ & $\begin{array}{c}\text { Group } 2 \\
\text { subgroups }\end{array}$ & $\begin{array}{c}\text { Group } 3 \\
\text { subgroups }\end{array}$ \\
\hline Morrison Fm, Wanakah Fm & Jmw & 1.7 & & \\
\hline Entrada Sandstone (Upper Jurassic) & $\mathrm{Je}$ & 1.6 & & 3.1 \\
\hline Summerville Fm, Entrada Sandstone & Jse & 1.6 & & 3.1 \\
\hline Kayenta Fm & TRk & 1.5 & & 3.1 \\
\hline Kayenta Fm, Wingate Fm & TRkw & 1.5 & & 3.1 \\
\hline Wingate Sandstone & $\mathrm{TRw}$ & 1.5 & & 3.1 \\
\hline Chinle Fm & $\mathrm{TCr}$ & 1.4 & & 3.1 \\
\hline Cutler Fm (Lower Permian) & $\mathrm{Pc}$ & 1.3 & & 3.1 \\
\hline Hermosa Fm (Pennsylvanian) & $\mathrm{Ph}$ & 1.3 & & 3.1 \\
\hline Mississippian and Devonian rocks & MDr & 1.2 & & \\
\hline \multicolumn{5}{|c|}{ Precambrian rock units } \\
\hline Granitic rocks (Precambrian Y- 1; 400 Ma age group) & $\mathrm{Yg}$ & 1.1 & & \\
\hline Uncompahgre Fm (Precambrian Y and X) & $\mathrm{YXu}$ & 1.1 & & \\
\hline Granitic rocks undivided (Precambrian $\mathrm{Y}$ and $\mathrm{X}$ ) & $\mathrm{pC}$ & 1.1 & & \\
\hline Granitic rocks undivided (Precambrian $\mathrm{Y}$ and $\mathrm{X}$ ) & $\mathrm{pCr}$ & 1.1 & & \\
\hline
\end{tabular}

Because land use can modify the degree of percolation, it is reasonable to assume that salt and selenium transport also can be influenced.

To ascertain the effect of land use on salt and selenium transport, land uses within each subbasin were analyzed. Geospatial data from "Colorado's Decision Support System-2000 irrigated parcels" (TechniGraphicS, Inc., 2004) were used to define the irrigated land within the lower Gunnison River study area. Evaluation of this dataset provided estimates of irrigated land by subbasin, in units of total area and percentage of subbasin area. This dataset uses 11 crop categories for agricultural land use: alfalfa, corn grain, dry beans, grapes, grass pasture, orchard, small grains, sod farm, sunflowers, vegetables, and wheat. The irrigated lands within the study area typically are near streams and close to an irrigation network (fig. 1).

\section{Irrigation Water Application}

Complicating the effects of vegetation on salt and selenium transport is the timing and amount of irrigation application, which changes physical and chemical hydrogeologic processes. Various irrigation methods can result in different amounts of percolation. Colorado's Decision Support System irrigated-lands dataset (TechniGraphicS, Inc., 2004) specifies crop type and irrigation method for each irrigated-lands area. 
Data that quantify the amounts of irrigation application are not directly available; however, by using the available geospatial data, these amounts can be estimated. Several assumptions were built into the estimates used for this report:

(1) irrigation water is applied to maximize potential yield for the specified crop (that is, irrigation water is applied to fully meet the consumptive water use of each crop without any excess or deficit);

(2) each irrigation method has a quantifiable efficiency;

(3) consumptive water use of each crop is linearly related to the length of the growing season (thus irrigation application will be greater in areas with more frost-free days); and

(4) effective precipitation (precipitation during the growing season that infiltrates the soil within the root zone of the crops) directly reduces the amount of irrigation water needed to maximize the yield of each crop.

A method for estimating the amount of irrigation application that conforms to these assumptions is available from the Colorado State University Cooperative Extension Service (Broner and Schneekloth, 2003). The water applied to each crop is estimated by using the following equation:

$$
I_{i}=[(W \times G)-P] / M
$$

where $I_{i}$ is the amount of irrigation water applied (inches of water) for crop $i$ during the growing season, $W$ is the mean consumptive water use for crop $i$ (in inches of water per growth-season day) obtained from U.S. Department of Agriculture Soil Conservation Service's Colorado irrigation guide (1988), $G$ is the mean growth season (in number of frost-free days), $P$ is the mean effective precipitation (in inches of water per growth season), and $M$ is the decimal percent efficiency of the irrigation method: 0.25 for flood irrigation, 0.40 for furrow, 0.65 for gated pipe, 0.75 for sprinkler, and 0.90 for drip (Waskom, 1994).

The mean growth season, $G$ in equation 5, was determined by using the following regression equation, calibrated with data from 130 Colorado climate stations:

$$
G=250-0.0573 H
$$

where $H$ is the climate-station elevation (in feet) (fig. 5). Frostfree days were determined for each climate station by using information available from the National Climatic Data Center (2005). The values used were those that indicated no more than a 10-percent probability that the temperature would drop below 32 degrees Fahrenheit. Climate-station elevation ranged from 3,390 to $11,320 \mathrm{ft}$, and the frost-free period at a given climate station ranged from 56 to 212 days.

The mean effective precipitation, $P$ in equation 5 , was calculated for nine towns in Colorado (Cortez, Delta, Durango, Fruita, Gunnison, Meeker, Monte Vista, Norwood, and Salida; fig. 1) by using data provided in Broner and Schneekloth (2003) and from the U.S. Department of

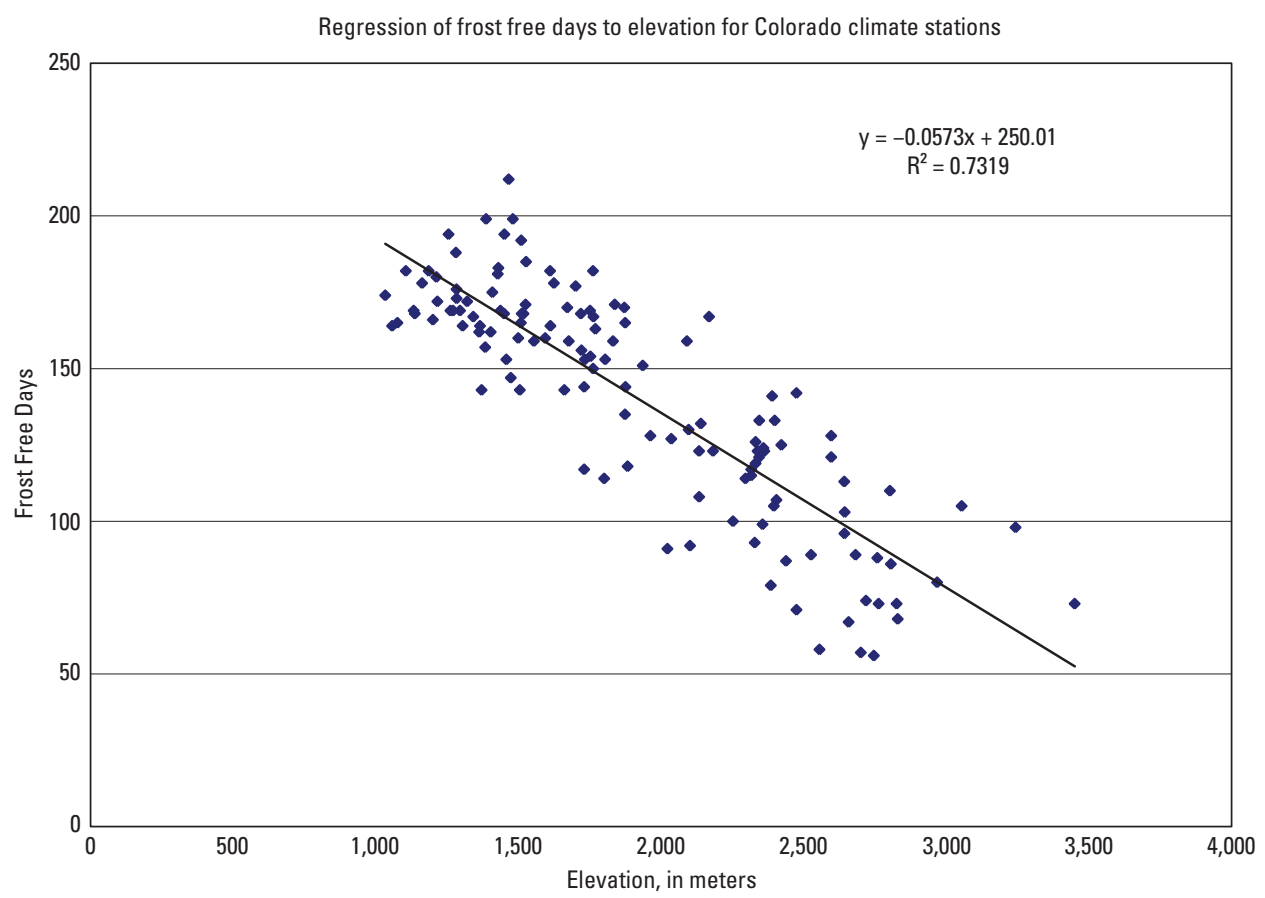

Figure 5. Relation of frost-free days at a climate station in the lower Gunnison River study area to climate-station elevation. 
Agriculture Soil Conservation Service (1988). Mean effective precipitation ranged from 3.80 to 8.34 in., whereas mean precipitation ranged from 7.25 to $18.59 \mathrm{in}$. On the basis of these data, a regression model (fig. 6) was calibrated to relate mean effective precipitation $(P)$ with mean total precipitation $\left(P_{R}\right)$, both in inches, during the growing season. By use of these relations, mean effective precipitation for any site in the study area can be estimated from mean precipitation by using the following equation:

$$
P=1.24+0.3266 P_{R}
$$

Equations 5,6, and 7 provide a means for estimating the amount of irrigation water applied to areas with a specific crop type and irrigation method. Total irrigation application $\left(I_{T}\right.$, in acre-feet) within a given subbasin was calculated by summing the irrigation requirements for areas with each combination of crop and irrigation method:

$$
I_{T}=\sum_{i=1}^{n} \sum_{j=1}^{5}\left(A_{i j} \frac{I_{i j}}{12}\right)
$$

where $A_{i j}$ is the area of crop $i$ irrigated by using method $j$ (in acres), and $I_{i j}$, is the amount of irrigation water applied to crop $i$ by using method $j$ (in inches), obtained from equation 5 . Application required for various crops ranged from 0.2 to 2.3 acre-feet (acre-ft) (fig. 7).

\section{Irrigation Channels}

Irrigation channels (canals and laterals) can lose water by seepage through the wetted surface of the channel bed and thus increase groundwater volume (Butler and others, 1996). The amount of seepage leaving a given irrigation channel is highly variable and depends on relative groundwater gradient, soil texture and transmissivity, permeability of the channel-bed sediments, and the magnitude, timing, and duration of flow. Complicating this inherent variability, the design of a channel, specifically its cross-sectional dimensions and area, produces variations in flow capacity and wetted perimeter. Potential seepage losses within individual subbasins were evaluated by estimating the total wetted area of unlined irrigation channels.

Wetted perimeter $(C$, in feet) of an irrigation channel was estimated by regression on channel flow capacity $(Q$, in cubic feet per second). Geospatial data representing the irrigation

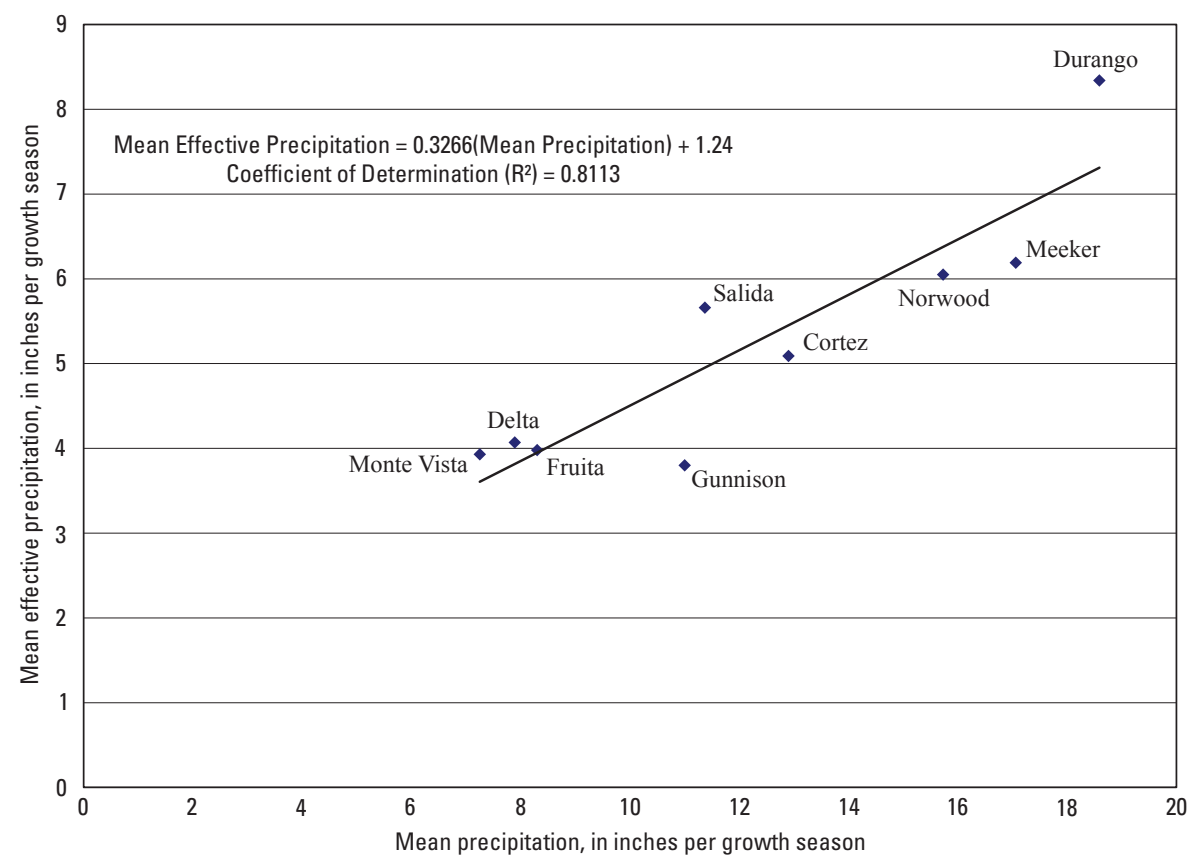

Figure 6. Relation of mean effective precipitation to mean precipitation at nine climate stations in and near the lower Gunnison River study area. 


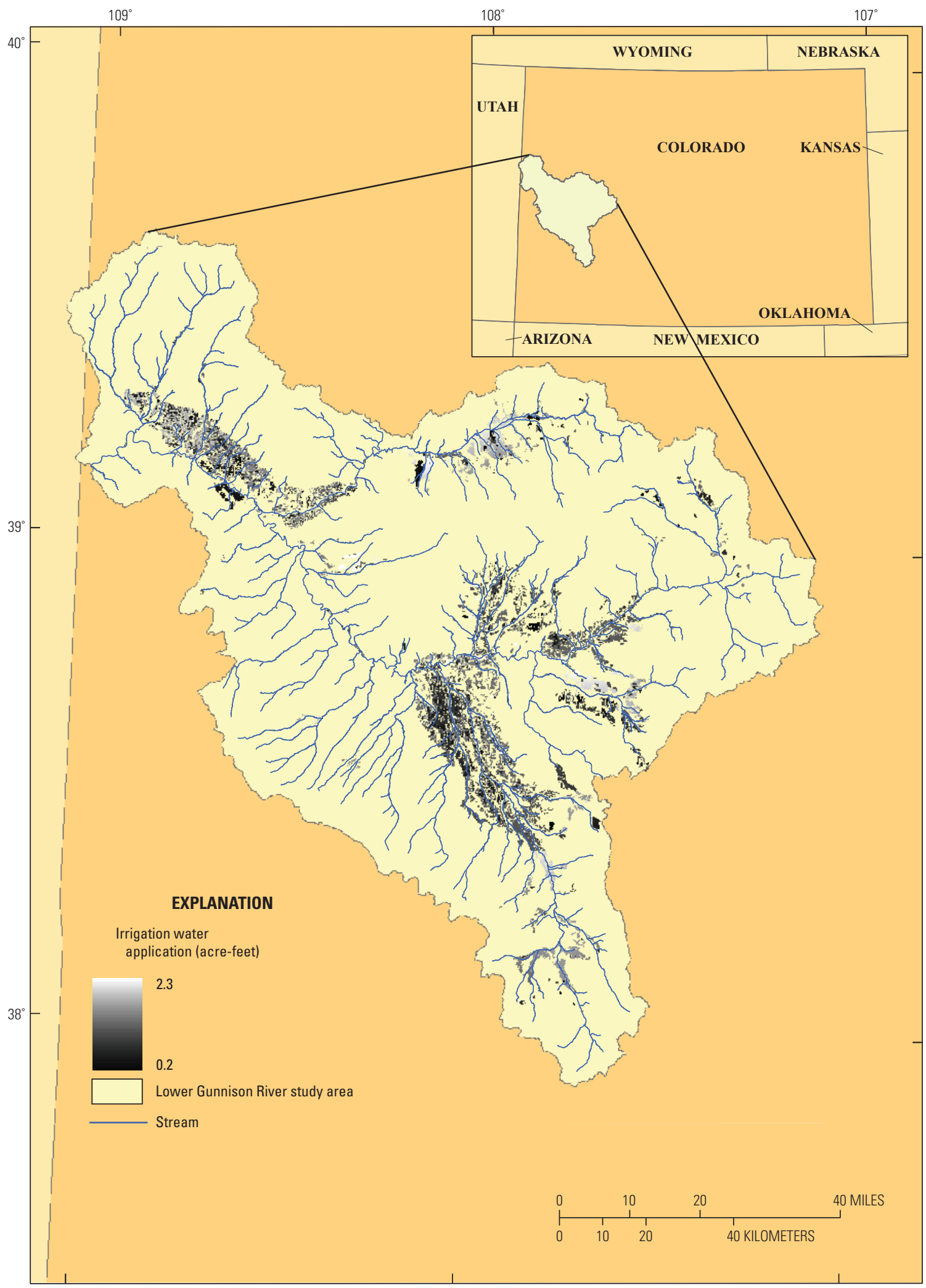

Figure 7. Estimated irrigation water applied within the lower Gunnison River study area. 
network were obtained from the NHD (U.S. Geological Survey, 1999b). Channel cross-section data from 20 irrigation network sites were used to develop the following equation (fig. 8):

$$
C=10.155+0.0924 Q \text {. }
$$

In order to simplify the geospatial analysis, channels were grouped into three categories on the basis of flow capacity: type I, $1-100$ cubic feet per second $\left(\mathrm{ft}^{3} / \mathrm{s}\right)$; type II, $101-300 \mathrm{ft}^{3} / \mathrm{s}$; and type III, 301-850 ft $3 / \mathrm{s}$. These categories were selected on the basis of the availability of flow data for each channel and the availability of channel wetted perimeters measured in channels within these three ranges of flow. Mean wetted perimeter for each category was computed by using equation 9, with $Q$ equal to the midpoint of the range in flow capacity. The total wetted area of channels $\left(C A_{T}\right)$ in a subbasin was calculated:

$$
C A_{T}=\sum_{i=1}^{3}\left(T_{i} \times C_{i} \times R\right),
$$

where $T_{i}$ is the total length (in feet) of all unlined type $i$ channels in the subbasin, $C_{i}$ is the wetted perimeter for channel type $i$ (in feet), and $R$ is a constant used to convert units from square feet to acres $\left(2.29 \times 10^{-5}\right)$. Lined sections of irrigation channels were assumed to have no seepage, so they were not included in the calculation of total channel length.

\section{Statistical Procedures}

Geospatial variables were evaluated for subbasins upstream from each water-quality sample site. Each variable was evaluated for its relation with the mean seasonal salt and selenium loads estimated at the subbasin outlets. The values of geospatial variables ranged widely among subbasins. For example, subbasin area ranged from about 170 to more than $3,700,000$ acres, and precipitation during the irrigation season ranged from 5.49 to 18.98 acre-ft. To minimize the disparity of geospatial variable values, they were logarithmically transformed. In order to avoid undefined transformations (for values of zero), a 1 was added to each value for all variables that had zero values in their range. The transformed values for each geospatial variable were used in simple linear regression analyses with mean seasonal salt and selenium loads. Regression coefficients were determined by using the weighted least-squares method (Helsel and Hirsch, 1992). Weights were based on the number of water-quality samples used to calculate the seasonal load for each subbasin.

The significance of relations between individual geospatial variables and the various salt and selenium loads was used to select candidate variables for multiple regression models. Separate models were developed for salt and selenium loading and for the irrigation and nonirrigation seasons. Each model was developed by using a stepwise procedure. Plots of residuals were analyzed to subjectively assess the occurrence of desirable characteristics such as homoscedasticity (similarity of variance) and normal distribution. These conditions help ensure that outliers did not influence the model. A p-value

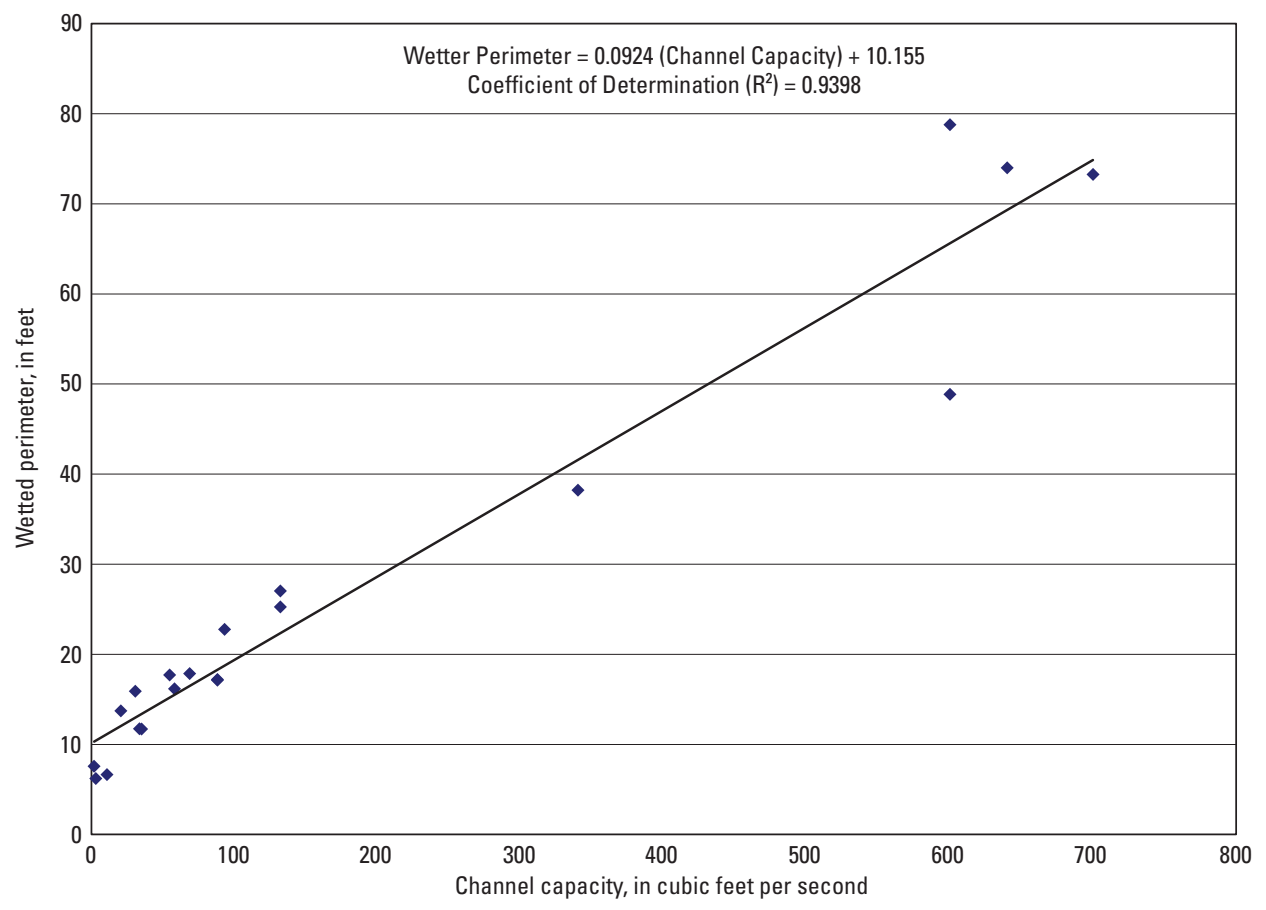

Figure 8. Relation of channel wetted perimeter to channel capacity in the lower Gunnison River study area. 
upper limit of 0.01 was the first criterion used to select variables for inclusion in the stepwise approach. Additional variables were included in multiple-linear regression models until no gains in statistical significance of a model were achieved. Once the qualifying variables were selected, a step-backward approach further refined the models. By evaluating all possible combinations of variables and recording the corresponding statistics, the influence of individual variables on model performance was evaluated.

Optimal groupings of various explanatory variables were assessed and used to establish four models to estimate irrigation-season salt load, nonirrigation-season salt load, irrigation-season selenium load, and nonirrigation-season selenium load. Selection of final variables for each model was based on obtaining a coefficient of determination $\left(R^{2}\right)$ greater than or equal to 0.70 and an overall p-value less than 0.05 . Root-mean-square (standard) error and residual characteristics, such as homoscedasticity and normal distribution, also were considered. In addition, the leverage and influence of each subbasin were calculated for each model to identify sites exerting unrealistic influence on the models. Explanatory variables that result in either very low or very high values in the $x$ direction have high leverage and can affect the slope of the regression (Ott and Longnecker, 2001). A high leverage point that corresponds with an outlier in the $y$ direction is a point that has high influence (Ott and Longnecker, 2001). Leverage was calculated by using the leverage statistic $h_{i}$ and influence by using the DFFITS statistic as defined by Helsel and Hirsch (1992). Different combinations of explanatory variables change the leverage and influence each sample site had on a regression equation. Models were selected such that sample sites had neither high leverage nor high influence as defined by Helsel and Hirsch (1992).

Once each regression equation was determined, it was necessary to evaluate how well the model estimated observed loads. The 95-percent prediction intervals for salt and selenium load estimates were determined by using equations defined by Helsel and Hirsch (1992). Observed loads (calculated from the measured water-quality data) for each subbasin were compared with these interval estimates.

\section{Relation of Salt and Selenium Loads to Geospatial Characteristics}

The relation between seasonal constituent loads and subbasin geospatial characteristics was evaluated by regression analysis by using 103 geospatial variables (appendixes A and B). Of these variables, 46 were expressed in units of both area and percentage of subbasin area. For each of the four response variables (salt and selenium loads during the irrigation and nonirrigation seasons), relations were statistically significant ( $p$ less than 0.01) for more than one-half of the explanatory geospatial variables: 67 variables for salt load during irrigation season, 71 for salt load during nonirrigation season, 66 for selenium load during irrigation season, and 71 for selenium load during nonirrigation season (appendixes A and B).

All geospatial variables with units of area had statistically significant relations with load. A few variables, in units other than area, had significant relations with load. These variables represented the subbasins' physical characteristics, such as elevation, precipitation, geology, land use, irrigation water applied, and irrigation channels. Maximum and minimum elevation and change in elevation were significantly related to irrigation and nonirrigation season salt and selenium loads. Mean subbasin elevation was significantly related to only the nonirrigation season loads. Subbasin precipitation was significantly related to nonirrigation season loads of salt and selenium. Of the 34 subgroups of geologic units, 7 (subgroups 3.2, 3.1, 1.10, $1.9,1.7,1.5$, and 1.4 (table 1)) were significantly related to salt and selenium loads, in percentage of subbasin area, during both the irrigation and nonirrigation seasons. These seven subgroups of geologic units can be divided by age and rock type into two general categories: Cretaceous marine shale, which had a positive correlation with loads, and Jurassic and older sandstone, which had a negative correlation with loads. Irrigation water applied, in acre-feet per subbasin, was the most strongly significant explanatory variable in units other than area.

Several geospatial variables were significantly related to loads but were of limited extent in the lower Gunnison River study area. For instance, groups of geologic units composed of Jurassic and older sandstones are found only in the westernmost part of the study area, contain little salt or selenium, and contribute little water to streams. These variables were not considered as candidate explanatory variables for multiple-regression models. Similarly, some crops, such as grapes, were not grown in every subbasin and, where they were grown, they occupied a very small percentage of the total subbasin area (less than 0.02 percent). Thus, environmental processes related to growing these crops probably would have a very limited influence on salt or selenium loads. Because the significance of crop-specific land-use variables and irrigated land-use in general were not consistent, and because groups of geologic units associated with Mancos Shale were significant, these variables were combined to form a new variable representing the area of Mancos Shale that was irrigated within a subbasin.

\section{Salt and Selenium Loading Models}

Different groupings of explanatory variables were assessed in a stepwise manner and the optimum groupings were used to establish four models that could estimate the following: irrigation-season salt load $\left(S_{T}\right)$, nonirrigation-season salt load $\left(S_{N I}\right)$, irrigation-season selenium load $\left(\mathrm{Se}_{I}\right)$, and nonirrigationseason selenium load $\left(S e_{N I}\right)$. The final models incorporated patterns that began to emerge during development of the model. The variables with the strongest statistically significant correlation with salt and selenium loads, when combined into multiple-linear-regression models, were subbasin area (in acres), area of irrigated Mancos Shale in the subbasin (in acres), area 
of irrigation channels in the subbasin (in acres), irrigation water applied (in acre-feet), precipitation during the irrigation season (in inches), and precipitation during the nonirrigation season (in inches). Although precipitation during the irrigation season was not significantly related to irrigation-season salt or selenium loads, the stepwise process indicated that its inclusion in the final models helped explain some of the variability of loads. Some of the effect of these variables on simulated loads is, admittedly, a result of the range of their values being connected to the area of their subbasin: smaller values occur in smaller subbasins and larger values occur in larger subbasins. Although this fact does not limit the utility of the models, it does pose a problem when one tries to determine why subbasins of similar size and streamflow produce different loads.

The four regression models and their associated variables are presented below:

$$
\begin{gathered}
\ln \left(S_{I}\right)=0.5504 \cdot \ln (S A)+0.2264 \cdot \ln (I M+1)+0.9163 \\
\begin{array}{c}
\ln \left(S_{N I}\right)=0.2742 \cdot \ln (S A)+0.1458 \cdot \ln (I M+1)+0.1347 \\
\ln \left(C A_{T}+1\right)+0.3484 \cdot \ln \left(I_{T}+1\right)-2.2608 \\
\ln \left(S e_{I}\right)=0.5674 \cdot \ln (S A)+0.3374 \cdot \ln (I M+1)-2.1574 \cdot \\
\ln (P I+1)+0.9614 \\
\ln \left(S e_{N I}\right)=0.3633 \cdot \ln (I M+1)+0.7171 \cdot \ln \left(C A_{T}+1\right) \\
-1.4476 \cdot \ln (P N I+1)-2.7976
\end{array}
\end{gathered}
$$

where: $S A$ is subbasin area (in acres), $I M$ is area of irrigated Mancos Shale in the subbasin (in acres); $C A_{T}$ is the estimated wetted area of unlined irrigation channels in the subbasin (in acres), from equation $10 ; I_{T}$ is the estimated amount of irrigation application (in acre-feet), from equation $8 ; P I$ is irrigation season precipitation (in inches), and $P N I$ is nonirrigation season precipitation (in inches). Various statistics for these models are listed in table 2 . The distribution of residuals was reasonably homoscedastic and normal for each model, and there were no sites that had either leverage or influence in any model.

Estimated salt and selenium loads would be expected to be similar to observed loads (calculated from the measured water-quality data) for any given subbasin if the models accurately represent loading processes. Salt and selenium data obtained during a period of several years provide a range of load values for each sample site. To discern the effectiveness of the models at estimating seasonal loads, 95-percent prediction intervals were calculated for loads estimated by using each model (fig. 9). Estimates outside the prediction interval were consistently linked with subbasins for which seasonal loads were determined from a single sample rather than as the mean of several samples. The width of the prediction intervals was generally about two orders of magnitude. This large range of uncertainty may be inadequate to estimate loads at individual points, but the intervals are considered to

\begin{tabular}{|c|c|c|c|c|c|c|}
\hline $\begin{array}{l}\text { Load-prediction } \\
\text { model }\end{array}$ & $\begin{array}{l}\text { Explanatory } \\
\text { variable }\end{array}$ & $R^{2}$ & P-value & $\begin{array}{l}\text { Degree of } \\
\text { freedom }\end{array}$ & $\begin{array}{c}\text { Standard } \\
\text { error }\end{array}$ & $\begin{array}{l}\text { Coefficient } \\
\text { of variation }\end{array}$ \\
\hline \multirow[t]{3}{*}{$S_{I}$} & & 0.82 & 0.00 & 79 & 4.27 & 1.35 \\
\hline & Subbasin Area & & 0.00 & & & \\
\hline & Area of Irrigated Mancos & & 0.00 & & & \\
\hline \multirow[t]{5}{*}{$S_{N I}$} & & 0.89 & 0.00 & 140 & 1.69 & 0.66 \\
\hline & Subbasin Area & & 0.00 & & & \\
\hline & Area of Irrigated Mancos & & 0.05 & & & \\
\hline & Wetted Area of Unlined Irrigation Channels & & 0.00 & & & \\
\hline & Irrigation Application & & 0.00 & & & \\
\hline \multirow[t]{4}{*}{$S e_{I}$} & & 0.70 & 0.00 & 82 & 4.38 & 4.47 \\
\hline & Subbasin Area & & 0.00 & & & \\
\hline & Area of Irrigated Mancos & & 0.00 & & & \\
\hline & Irrigation Season Precipitation & & 0.01 & & & \\
\hline \multirow[t]{4}{*}{$S e_{N I}$} & & 0.79 & 0.00 & 151 & 2.70 & 1.85 \\
\hline & Area of Irrigated Mancos & & 0.00 & & & \\
\hline & Wetted Area of Unlined Irrigation Channels & & 0.00 & & & \\
\hline & Nonirrigation Season Precipitation & & 0.00 & & & \\
\hline
\end{tabular}
be adequate to identify, or rank, subbasins in terms of relative salt and selenium contribution within the lower Gunnison River study area.

Table 2. Statistical values of the seasonal salt and selenium load-prediction models.

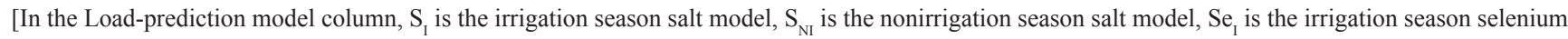
model, and $\mathrm{Se}_{\mathrm{NI}}$ is the nonirrigation selenium model; $R^{2}$ is the coefficient of determination] 

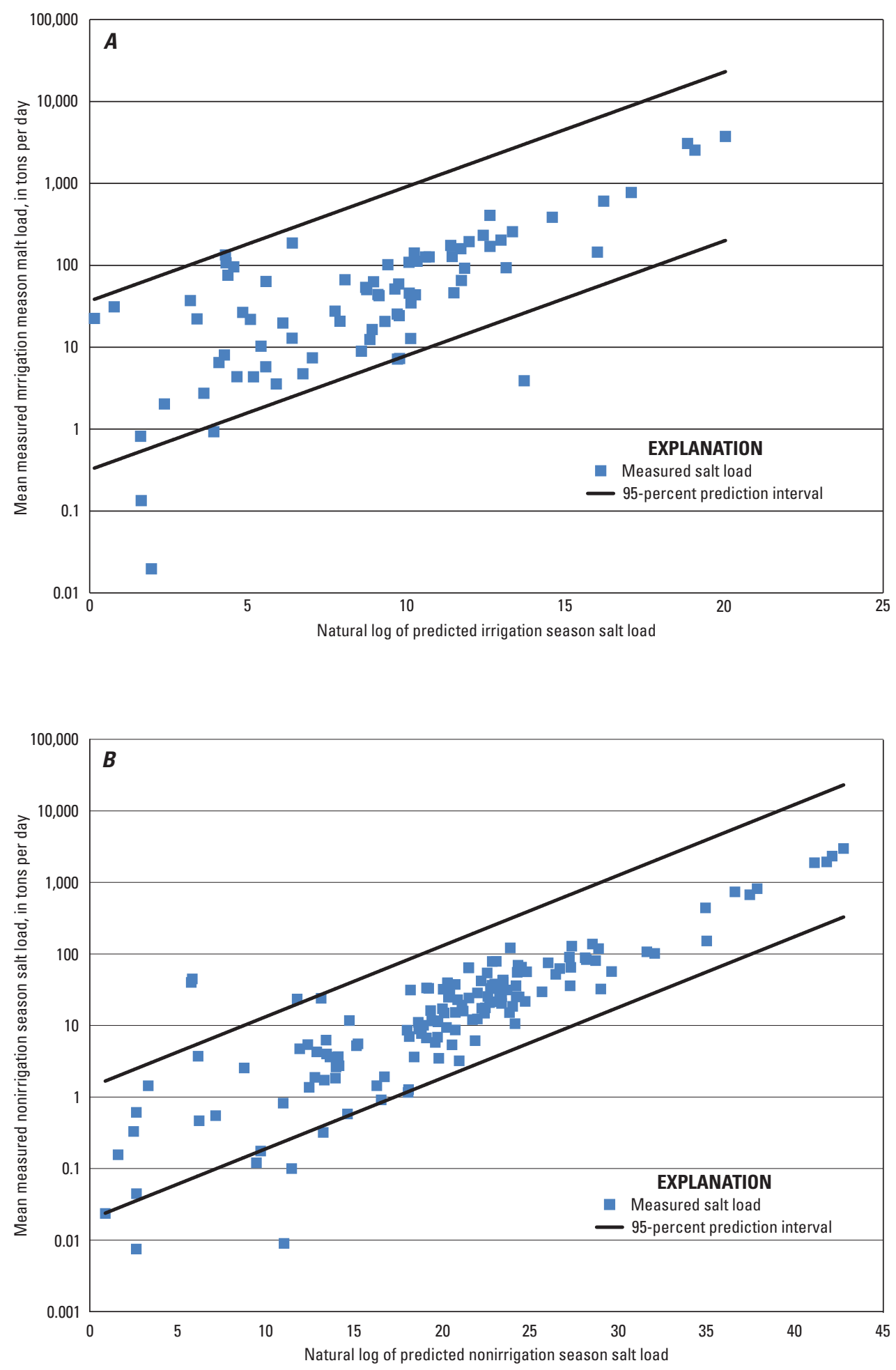

Figure 9. Relation of mean measured loads to model estimated loads for $(A)$ irrigation season salt load, $(B)$ nonirrigation season salt load, $(C)$ irrigation season selenium load, $(D)$ nonirrigation season selenium load. 

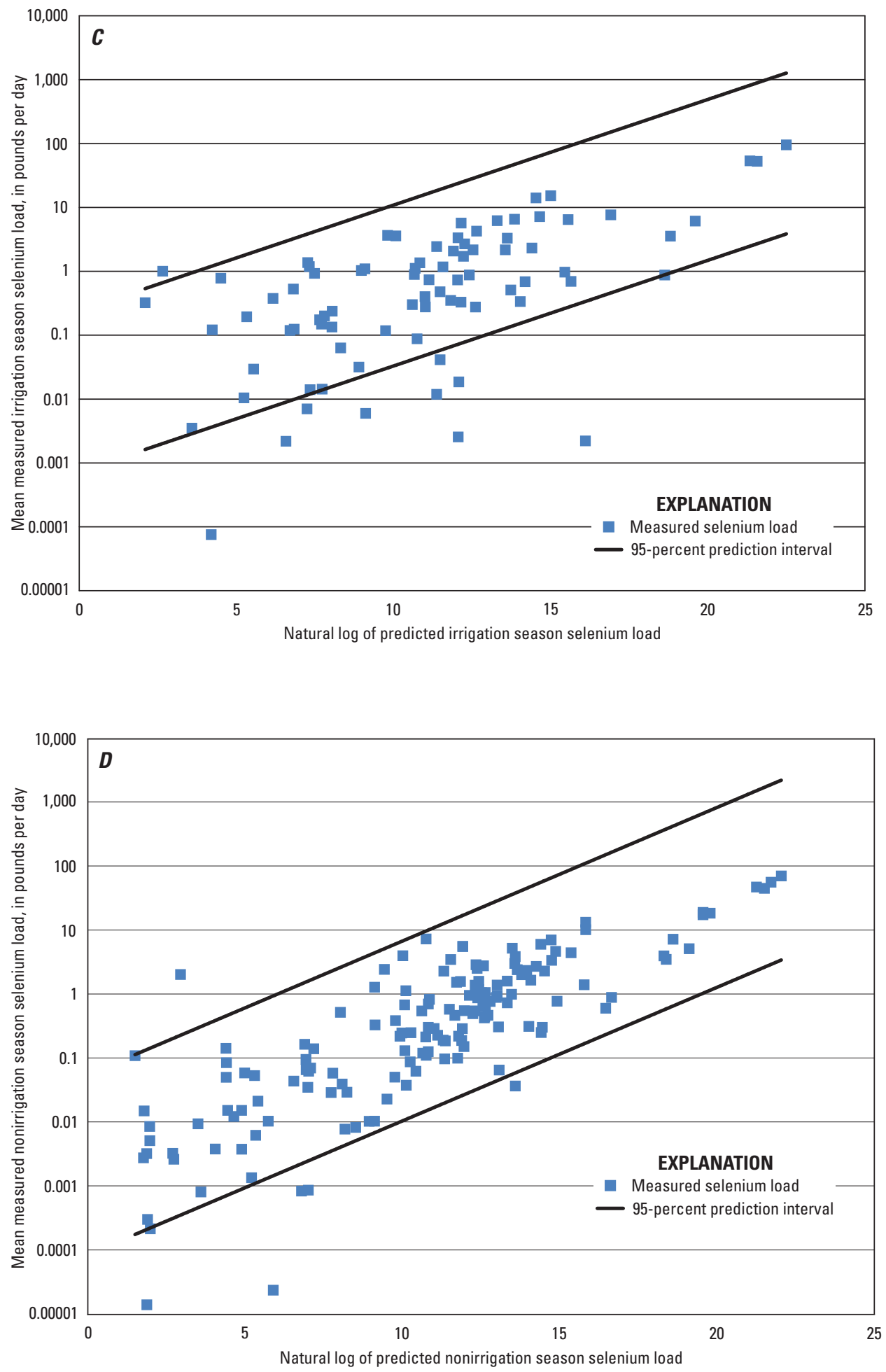

Figure 9.-Continued Relation of mean measured loads to model estimated loads for $(A)$ irrigation season salt load, $(B)$ nonirrigation season salt load, $(C)$ irrigation season selenium load, $(D)$ nonirrigation season selenium load. 


\section{Possible Improvements in Statistical Methods and Models}

Considerable latitude exists for improving the input datasets and refining the statistical models used to evaluate relations between geospatial variables and salt and selenium loads. New geospatial datasets such as those related to soils, surficial geology, evapotranspiration, and irrigation may provide better statistical relations with salt and selenium loading. Refinements of current geospatial data, such as improvements in representing irrigation channels, estimating amount of irrigation application, or delineating land use, might also be beneficial because these geospatial data are already used in the models. With respect to the models, more robust methods of limiting the disparity between explanatory variable values might be used (such as data transformations and data centering; Helsel and Hirsch, 1992).

To facilitate management decisions, a graphical user interface might be developed to easily identify the estimated load from a given area. The interface might include scenario tools for examining how changes in resource management might affect salt and selenium loading. Management practices could include lining irrigation channels, converting land to a different land use, or using a different method of applying irrigation water. Additionally, the possible effects of climate change, such as changes in the amount and temporal distribution of precipitation could be examined. These future products might help provide resource managers with the tools necessary to understand the factors influencing salt and selenium loading and help indicate where salt and selenium control projects might be most effective.

\section{Summary}

Elevated loads of salt and selenium can reduce the quality of water for both anthropogenic and natural uses. An understanding of the environmental processes controlling how salt and selenium are introduced to streams is needed to help manage and mitigate the effects of those elevated loads. The principal processes by which salt and selenium are introduced to the hydrologic environment are the dissolution of salts from porous media and the oxidation and mobilization of selenium from bedrock by groundwater. In areas of the Upper Colorado River Basin of western Colorado, irrigation has become prevalent as land cover has been converted from native vegetation to agricultural crops. Complex surface and subsurface processes that influence the amount of salt and selenium gained by streams make it difficult for land managers to prioritize implementation of salinity-control practices.

The USGS, in cooperation with the Bureau of Reclamation, investigated statistical relations between seasonal loads of salt and selenium emanating from the Upper Colorado River Basin and geospatial characteristics. Geospatial datasets were evaluated for 168 subbasins within parts of the Gunnison and Colorado River Basins composing the lower Gunnison River study area. Geospatial variables derived from these datasets represent basin physical characteristics, precipitation, geology, land use, and the irrigation network. These variables were evaluated in comparison to salt and selenium loads calculated by using water-quality data at corresponding sample sites. All geospatial variables with units of area had statistically significant relations with salt and selenium loads at subbasin outlet sites. The few variables in units other than area that were statistically significant helped to identify processes that might influence salt and selenium loading. By using geospatial variables that had the most significant relations with seasonal loads of salt and selenium, multiple-linear regression models were developed to estimate loads from subbasins in the lower Gunnison River study area.

Considerable latitude exists for improving the input data sets and refining the statistical models used to evaluate relations between salt and selenium loads and geospatial variables. Additionally, a graphical user interface might be developed to easily identify the estimated load from a given area and estimate the effects of potential resource management decisions. These future products might help provide resource managers with the tools necessary to understand the factors influencing salt and selenium loading and help indicate where salt and selenium control projects might be most effective.

\section{References Cited}

Anning, D.W., Bauch, N.J., Gerner, S.J., Flynn, M.E., Hamlin, S.N., Moore, S.J., Schaefer, D.H., Anderholm, S.K., and Spangler, L.E., 2006, Dissolved solids in basin-fill aquifers and streams in the southwestern United States: U.S. Geological Survey Scientific Investigations Report 2006-5315, 169 p.

Broner, Israel, and Schneekloth, Joel, 2003, Seasonal water needs and opportunities for limited irrigation for Colorado crops: Colorado State University Extension Fact Sheet 4.718, 4 p.

Bureau of Reclamation, 2009, Colorado River Basin Salinity Control Project: Accessed October 6, 2009, at http://www. usbr.gov/projects/Project.jsp?proj_Name $=$ Colorado + River + Basin+Salinity + Control + Project .

Butler, D.L., 1996, Trend analysis of selected water-quality data associated with salinity-control projects in the Grand Valley, in the lower Gunnison River Basin, and at Meeker Dome, western Colorado: U.S. Geological Survey WaterResources Investigations Report 95-4274, 38 p.

Butler, D.L., 2001, Effects of piping irrigation laterals on selenium and salt loads, Montrose Arroyo Basin, western Colorado: U.S. Geological Survey Water-Resources Investigations Report 01-4204, 18 p.

Butler, D.L., and Leib, K.J., 2002, Characterization of selenium in the lower Gunnison River Basin, Colorado, 1988-2000: U.S. Geological Survey Water-Resources Investigations Report 02-4151, 26 p. 
Butler, D.L., and von Guerard, P., 1996, Salinity in the Colorado River in the Grand Valley, western Colorado, 1994-95: U.S. Geological Survey Fact Sheet FS-215-96, 4 p.

Butler, D.L., Wright, W.G., Stewart, K.C., Osmundson, B.C., Krueger, R.P., and Crabtree, D.W., 1996, Detailed study of selenium and other constituents in water, bottom sediment, soil, alfalfa, and biota associated with irrigation drainage in the Uncompahgre area and in the Grand Valley, west-central Colorado, 1991-1993: U.S. Geological Survey Water-Resources Investigations Report 96-4138, $136 \mathrm{p}$.

Daly, C., Neilson, R.P., and Phillips, D.L., 1994, A statisticaltopographic model for mapping climatological precipitation over mountainous terrain: Journal of Applied Meteorology, v. 33 , p. $140-158$.

Day, W.C., Green, G.N., Knepper, D.H., Jr., and Phillips, R.C., 1999, Spatial geologic data model for the Gunnison, Grand Mesa, Uncompahgre National Forests mineral assessment area, southwestern Colorado and digital data for the Leadville, Montrose, Durango, and the Colorado parts of the Grand Junction, Moab, and Cortez $1^{\circ} \times 2^{\circ}$ geologic maps: U.S. Geological Survey Open-File Report 99-427, CD-ROM.

Fishman, M.J., and Friedman, L.C., 1989, Methods for the determination of inorganic substances in water and fluvial sediments: U.S. Geological Survey Techniques of WaterResources Investigations, book 5, chap. A1, 545 p.

Gates, T.K., Cody, B.M., Donnelly, J.P., Herting, A.W., Bailey, R.T., and Price, J.M., 2009, Assessing selenium contamination in the irrigated stream-aquifer system of the Arkansas River, Colorado: Journal of Environmental Quality, v. 38, p. 2344-2356.

Hamilton, S.J., 1998, Selenium effects on endangered fish in the Colorado River Basin, in Frankenberger, W.T., and Engberg, R.A., eds., Environmental chemistry of selenium: New York, Marcel Dekker, 713 p.

Hamilton, S.J., 1999, Hypothesis of historic effects from selenium on endangered fish in the Colorado River Basin: Human and Ecological Risk Assessment, v. 5, no. 6, p. 1153-1180.

Helsel, D.R., and Hirsch, R.M., 1992, Statistical methods in water resources: New York, Elsevier, 522 p.

Hedlund, J.D., 1994, Salt primer-Water and salt budgets: Portland, Ore., Soil Conservation Service West National Technical Center, $60 \mathrm{p}$.

Hintze, L.F., Willis, G.C., Laes, D.Y.M., Sprinkel, D.A., and Brown, K.D., 2000, Digital geologic map of Utah: Utah Geological Survey Map 179DM, scale 1:500,000. accessed February 14, 2011, at http://geology.utah.gov/maps/gis/ index.htm
Jenke, A.L., 1974, Evaluation of salinity created by irrigation return flows: Washington, D.C., U.S. Environmental Protection Agency Office of Water Programs EPA 430/9-74-006, $139 \mathrm{p}$.

Johnson, R.K., and Schumm, S.A., 1982, Geomorphic and lithologic controls of diffuse-source salinity Grand Valley, western Colorado: Fort Collins, Colorado Water Resources Research Institute Completion Report 110, 106 p.

Laronne, J.B., 1977, Evaluation of the storage of diffuse sources of salinity in the Upper Colorado River Basin: Fort Collins, Colorado Water Resources Research Institute Completion Report 79, 122 p.

Leib, K.J., 2008, Concentrations and loads of selenium in selected tributaries to the Colorado River in the Grand Valley, western Colorado, 2004-2006: U.S. Geological Survey Scientific Investigations Report 2008-5036, 45 p.

Lemly, A.D., 2002, Selenium assessment in aquatic ecosystems-A guide for hazard evaluation and water quality criteria: New York, Springer-Verlag, 161 p.

Mayo, J.W., 2008, Estimating the effects of conversion of agricultural land to urban land on deep percolation of irrigation water in the Grand Valley, western Colorado: U.S. Geological Survey Scientific Investigations Report 2008-5086, $58 \mathrm{p}$.

National Climatic Data Center, 2005, Data documentation for data set 9712C (DSI-9712C) — Probability levels for 1971-2000 freeze dates and growing season lengths: Asheville, N.C., National Climatic Data Center, 8 p.

Ott, R.L., and Longnecker, M., 2001, An introduction to statistical methods and data analysis: Pacific Grove, California, Duxbury Thompson Learning, $1152 \mathrm{p}$.

Polubarinova-Kochina, P.Y., 1962, Theory of ground water movement: Princeton, New Jersey, Princeton University Press, $613 \mathrm{p}$.

Ries, K.G., III, and Dillow, J.J.A., 2006, Magnitude and frequency of floods on nontidal streams in Delaware: U.S. Geological Survey Scientific Investigations Report 20065146, 59 p.

See, R.B., Naftz, D.L., Peterson, D.A., Crock, J.G., Erdman, J.A., Severson, R.C., Ramirez, P., Jr., and Armstrong, J.A., 1992, Detailed study of selenium in soil, representative plants, water, bottom sediment, and biota in the Kendrick Reclamation Project area, Wyoming, 1988-90: U.S. Geological Survey Water-Resources Investigations Report 91-4131, $142 \mathrm{p}$.

Seiler, R.L., Skorupa, J.P., and Peltz, L.A., 1999, Areas susceptible to irrigation-induced selenium contamination of water and biota in the western United States: U.S. Geological Survey Circular 1180, 36 p. 
Singh, Pratap, and Singh, V.P., 2001, Snow and glacier hydrology: Netherlands, Kluwer Academic Publishers, 742 p.

TechniGraphicS, Inc., 2004, Colorado's decision support systems - 2000 irrigated parcels: accessed March 8, 2012, at http://cdss.state.co.us/Pages/CDSSHome.aspx within the downloadable GIS Data, Division 4 Gunnison and Division 5 Colorado GIS Data Libraries.

U.S. Department of Agriculture Soil Conservation Service, 1988, Colorado irrigation guide: CO210-VI-COIG, 358 p.

U.S. Department of Agriculture, 1997, National engineering handbook - Irrigation guide: Natural Resources Conservation Service 210-vi-NEH, accessed October 6, 2009, at http://policy.nrcs.usda.gov/OpenNonWebContent. aspx? content $=17837$.wba

U.S. Geological Survey, 1998, National Water Information System (NWIS): U.S. Geological Survey Fact Sheet 02798, 2 p., accessed October 6, 2009, at http://nwis.waterdata. usgs.gov/co/nwis/qwdata

U.S. Geological Survey, 1999a, National Elevation Dataset: U.S. Geological Survey Fact Sheet 148-99, 2 p.

U.S. Geological Survey, 1999b, National Hydrography Dataset: U.S. Geological Survey Fact Sheet 106-99, 2 p.

Viger, R.J., and Leavesley, G.H., 2007, The GIS Weasel user's manual: U.S. Geological Survey Techniques and Methods, book 6, chap. B4, $201 \mathrm{p}$.

Waskom, R.M., 1994, Best management practices for irrigation management: Colorado State University Extension Bulletin XCM-173, 17 p.
Publishing support provided by:

Denver Publishing Service Center

For more information concerning this publication, contact: Director, USGS Colorado Water Science Center Box 25046, Mail Stop 415

Denver, CO 80225

(303) 236-4882

Or visit the Colorado Water Science Center Web site at: http://co.water.usgs.gov/ 
Appendix 


\section{Appendix A. Relation between Seasonal Salt Loads and Individual Geospatial Variables-Results of Simple Linear Regression Analysis of Seasonal Salt Loads.}

$\left[\mathrm{R}^{2}\right.$, coefficient of determination; bold P-values indicate statistically significance ( $\mathrm{p}$ less than 0.01$)$ and variables that were included in the multiple regression analysis]

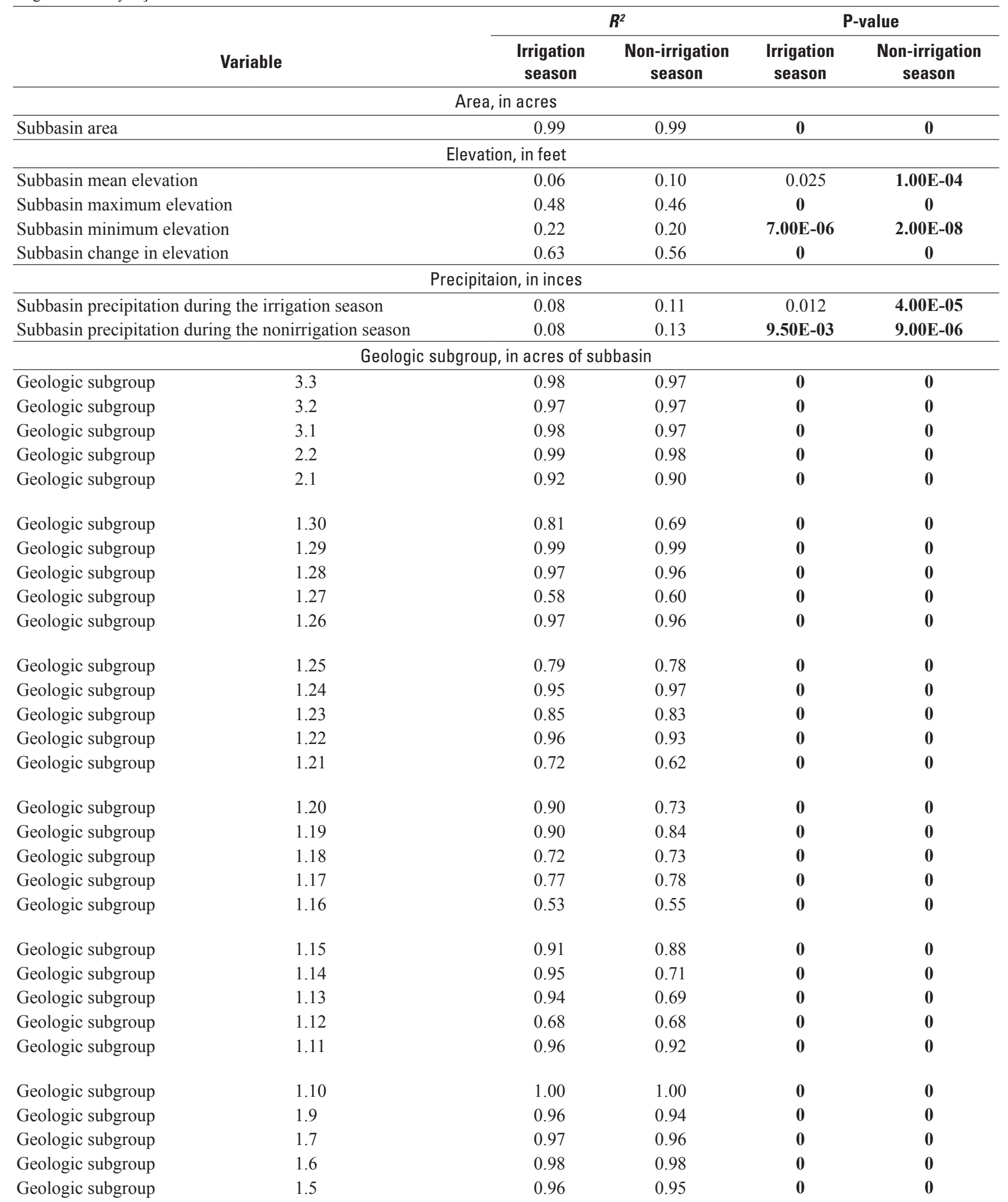




\section{Appendix A. Relation between Seasonal Salt Loads and Individual Geospatial Variables-Results of Simple Linear Regression Analysis of Seasonal Salt Loads. - Continued}

$\left[\mathrm{R}^{2}\right.$, coefficient of determination; bold P-values indicate statistically significance ( $\mathrm{p}$ less than 0.01 ) and variables that were included in the multiple regression analysis]

\begin{tabular}{|c|c|c|c|c|c|}
\hline \multirow{2}{*}{\multicolumn{2}{|c|}{ Variable }} & \multicolumn{2}{|c|}{$R^{2}$} & \multicolumn{2}{|c|}{ P-value } \\
\hline & & $\begin{array}{l}\text { Irrigation } \\
\text { season }\end{array}$ & $\begin{array}{c}\text { Non-irrigation } \\
\text { season }\end{array}$ & $\begin{array}{l}\text { Irrigation } \\
\text { season }\end{array}$ & $\begin{array}{c}\text { Non-irrigation } \\
\text { season }\end{array}$ \\
\hline Geologic subgroup & 1.4 & 0.97 & 0.95 & $\mathbf{0}$ & $\mathbf{0}$ \\
\hline Geologic subgroup & 1.3 & 0.93 & 0.91 & $\mathbf{0}$ & $\mathbf{0}$ \\
\hline Geologic subgroup & 1.2 & 0.76 & 0.64 & $\mathbf{0}$ & $\mathbf{0}$ \\
\hline Geologic subgroup & 1.1 & 0.97 & 0.95 & $\mathbf{0}$ & $\mathbf{0}$ \\
\hline \multicolumn{6}{|c|}{ Geologic subgroup, in percentage of subbasin area } \\
\hline Geologic subgroup & 3.3 & $1.10 \mathrm{E}-03$ & $2.40 \mathrm{E}-03$ & 0.765 & 0.561 \\
\hline Geologic subgroup & 3.2 & 0.13 & 0.12 & $7.00 \mathrm{E}-04$ & 2.00E-05 \\
\hline Geologic subgroup & 3.1 & 0.22 & 0.12 & 6.00E-06 & 2.00E-05 \\
\hline Geologic subgroup & 2.2 & $2.00 \mathrm{E}-05$ & $2.00 \mathrm{E}-05$ & 0.968 & 0.952 \\
\hline Geologic subgroup & 2.1 & 0.08 & 0.04 & 0.011 & 0.015 \\
\hline Geologic subgroup & 1.30 & $4.00 \mathrm{E}-04$ & $1.00 \mathrm{E}-04$ & 0.858 & 0.889 \\
\hline Geologic subgroup & 1.29 & 0.05 & 0.03 & 0.045 & 0.029 \\
\hline Geologic subgroup & 1.28 & $3.50 \mathrm{E}-03$ & $6.10 \mathrm{E}-03$ & 0.596 & 0.351 \\
\hline Geologic subgroup & 1.27 & $3.00 \mathrm{E}-05$ & $5.00 \mathrm{E}-04$ & 0.962 & 0.798 \\
\hline Geologic subgroup & 1.26 & 0.07 & 0.03 & 0.015 & 0.047 \\
\hline Geologic subgroup & 1.25 & $4.00 \mathrm{E}-05$ & $8.00 \mathrm{E}-04$ & 0.952 & 0.729 \\
\hline Geologic subgroup & 1.24 & $5.40 \mathrm{E}-03$ & $6.10 \mathrm{E}-03$ & 0.509 & 0.352 \\
\hline Geologic subgroup & 1.23 & $3.10 \mathrm{E}-03$ & $2.00 \mathrm{E}-06$ & 0.615 & 0.986 \\
\hline Geologic subgroup & 1.22 & $2.30 \mathrm{E}-03$ & 0.28 & 0.667 & 0.595 \\
\hline Geologic subgroup & 1.21 & $5.30 \mathrm{E}-03$ & $4.00 \mathrm{E}-04$ & 0.512 & 0.804 \\
\hline Geologic subgroup & 1.20 & $4.00 \mathrm{E}-04$ & $2.10 \mathrm{E}-03$ & 0.854 & 0.581 \\
\hline Geologic subgroup & 1.19 & 0.17 & 0.19 & 1.00E-04 & 4.00E- 08 \\
\hline Geologic subgroup & 1.18 & $5.60 \mathrm{E}-03$ & 0.01 & 0.502 & 0.188 \\
\hline Geologic subgroup & 1.17 & $8.30 \mathrm{E}-03$ & $5.40 \mathrm{E}-03$ & 0.413 & 0.379 \\
\hline Geologic subgroup & 1.16 & $5.00 \mathrm{E}-04$ & $1.00 \mathrm{E}-05$ & 0.844 & 0.965 \\
\hline Geologic subgroup & 1.15 & 0.07 & 0.06 & 0.019 & 2.70E-03 \\
\hline Geologic subgroup & 1.14 & 0.19 & 0.02 & 4.00E-05 & 0.079 \\
\hline Geologic subgroup & 1.13 & 0.01 & 0.01 & 0.325 & 0.209 \\
\hline Geologic subgroup & 1.12 & 0.02 & $7.00 \mathrm{E}-04$ & 0.215 & 0.744 \\
\hline Geologic subgroup & 1.11 & 0.13 & 0.06 & 8.00E-04 & $2.80 \mathrm{E}-03$ \\
\hline Geologic subgroup & 1.10 & 0.20 & 0.18 & 3.00E-05 & 1.00E-07 \\
\hline Geologic subgroup & 1.9 & 0.15 & 0.07 & 3.00E-04 & 9.00E-04 \\
\hline Geologic subgroup & 1.7 & 0.23 & 0.18 & 3.00E-06 & 1.00E-07 \\
\hline Geologic subgroup & 1.6 & 0.06 & 0.06 & 0.023 & $3.80 \mathrm{E}-03$ \\
\hline Geologic subgroup & 1.5 & 0.27 & 0.06 & 6.00E-07 & $2.40 \mathrm{E}-03$ \\
\hline Geologic subgroup & 1.4 & 0.22 & 0.12 & $9.00 \mathrm{E}-06$ & $3.00 \mathrm{E}-05$ \\
\hline Geologic subgroup & 1.3 & $3.70 \mathrm{E}-03$ & 0.02 & 0.586 & 0.108 \\
\hline Geologic subgroup & 1.2 & $4.20 \mathrm{E}-03$ & $2.00 \mathrm{E}-04$ & 0.561 & 0.866 \\
\hline Geologic subgroup & 1.1 & 0.03 & 0.04 & 0.145 & 0.013 \\
\hline
\end{tabular}




\section{Appendix A. Relation between Seasonal Salt Loads and Individual Geospatial Variables-Results of Simple Linear Regression Analysis of Seasonal Salt Loads. - Continued}

$\left[\mathrm{R}^{2}\right.$, coefficient of determination; bold P-values indicate statistically significance ( $\mathrm{p}$ less than 0.01 ) and variables that were included in the multiple regression analysis]

\begin{tabular}{|c|c|c|c|c|}
\hline \multirow[b]{2}{*}{ Variable } & \multicolumn{2}{|c|}{$R^{2}$} & \multicolumn{2}{|c|}{ P-value } \\
\hline & $\begin{array}{l}\text { Irrigation } \\
\text { season }\end{array}$ & $\begin{array}{l}\text { Non-irrigation } \\
\text { season }\end{array}$ & $\begin{array}{l}\text { Irrigation } \\
\text { season }\end{array}$ & $\begin{array}{l}\text { Non-irrigation } \\
\text { season }\end{array}$ \\
\hline \multicolumn{5}{|c|}{ Land Use, in acres of subbasin } \\
\hline Irrigated land & 1.00 & 0.99 & $\mathbf{0}$ & $\mathbf{0}$ \\
\hline Alfalfa & 0.97 & 0.96 & $\mathbf{0}$ & $\mathbf{0}$ \\
\hline Beans & 0.95 & 0.08 & $\mathbf{0}$ & $\mathbf{0}$ \\
\hline Corn & 0.99 & 0.95 & $\mathbf{0}$ & $\mathbf{0}$ \\
\hline Grapes & 0.71 & 0.73 & $\mathbf{0}$ & $\mathbf{0}$ \\
\hline Orchard & 0.99 & 0.96 & $\mathbf{0}$ & $\mathbf{0}$ \\
\hline Pasture & 0.99 & 0.98 & $\mathbf{0}$ & $\mathbf{0}$ \\
\hline Small grains & 0.97 & 0.94 & $\mathbf{0}$ & $\mathbf{0}$ \\
\hline Sod & 0.71 & 0.72 & $\mathbf{0}$ & $\mathbf{0}$ \\
\hline Sunflowers & 0.68 & 0.68 & $\mathbf{0}$ & $\mathbf{0}$ \\
\hline Vegetables & 0.97 & 0.94 & $\mathbf{0}$ & $\mathbf{0}$ \\
\hline Wheat & 0.65 & 0.60 & $\mathbf{0}$ & $\mathbf{0}$ \\
\hline \multicolumn{5}{|c|}{ Land Use, in percentage of subbasin area } \\
\hline Irrigated land & 0.07 & 0.07 & 0.015 & 1.50E-03 \\
\hline Alfalfa & 0.02 & 0.02 & 0.225 & 0.078 \\
\hline Beans & 0.06 & $4.00 \mathrm{E}-04$ & 0.024 & 0.804 \\
\hline Corn & 0.01 & 0.01 & 0.303 & 0.174 \\
\hline Grapes & 0.67 & 0.67 & $\mathbf{0}$ & $\mathbf{0}$ \\
\hline Orchard & $4.20 \mathrm{E}-03$ & $2.70 \mathrm{E}-03$ & 0.560 & 0.532 \\
\hline Pasture & 0.09 & 0.07 & $6.30 \mathrm{E}-03$ & 1.70E-03 \\
\hline Small grains & $2.00 \mathrm{E}-04$ & $1.10 \mathrm{E}-03$ & 0.911 & 0.691 \\
\hline Sod & 0.71 & $9.00 \mathrm{E}-04$ & $\mathbf{0}$ & 0.708 \\
\hline Sunflowers & $2.10 \mathrm{E}-03$ & $3.20 \mathrm{E}-03$ & 0.680 & 0.503 \\
\hline Vegetables & $4.50 \mathrm{E}-03$ & $5.90 \mathrm{E}-03$ & 0.547 & 0.355 \\
\hline Wheat & $9.20 \mathrm{E}-03$ & 0.01 & 0.387 & 0.199 \\
\hline Irrigation water applied, in acre-ft per subbasin & 0.99 & 0.99 & $\mathbf{0}$ & $\mathbf{0}$ \\
\hline Irrigation water applied, in acre-ft per square mile of subbasin & 0.08 & 0.07 & 0.012 & 1.10E-03 \\
\hline Area of irrigation channels, in acres of subbasin & 0.97 & 0.97 & $\mathbf{0}$ & 0 \\
\hline Area of irrigated Mancos Shale, in acres of subbasin & 0.96 & 0.98 & 0 & $\mathbf{0}$ \\
\hline
\end{tabular}




\section{Appendix B. Relation between Seasonal Selenium Loads and Individual Geospatial Variables-Results of Simple Linear Regression Analysis of Seasonal Selenium Loads.}

$\left[\mathrm{R}^{2}\right.$, coefficient of determination; bold P-values indicate statistically significant values ( $\mathrm{p}$ less than 0.01 ) and variables that were included in the multiple regression analysis]

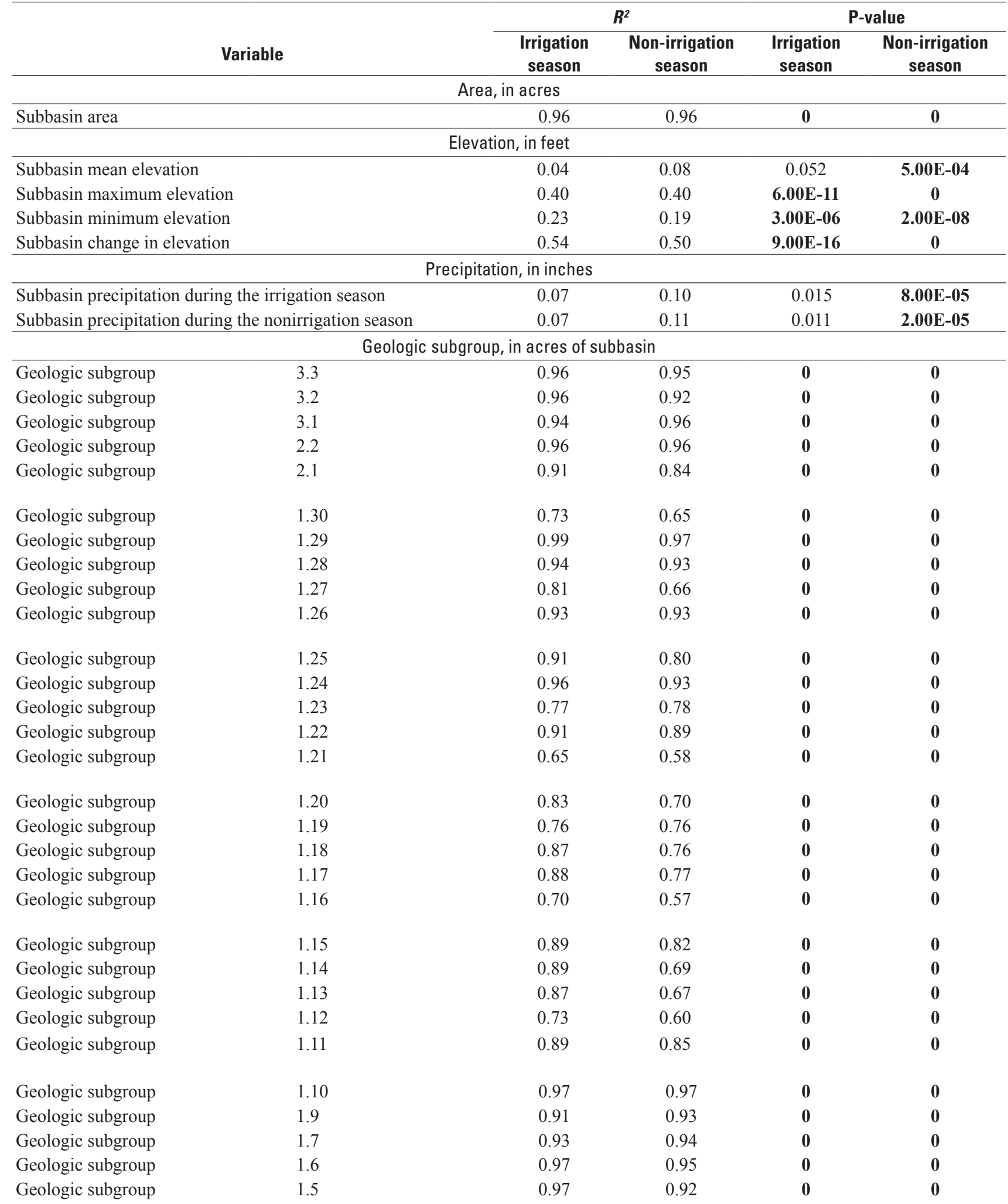




\section{Appendix B. Relation between Seasonal Selenium Loads and Individual Geospatial Variables-Results of Simple Linear Regression Analysis of Seasonal Selenium Loads. - Continued}

$\left[\mathrm{R}^{2}\right.$, coefficient of determination; bold P-values indicate statistically significant values ( $\mathrm{p}$ less than 0.01 ) and variables that were included in the multiple regression analysis]

\begin{tabular}{|c|c|c|c|c|c|}
\hline \multirow{2}{*}{\multicolumn{2}{|c|}{ Variable }} & \multicolumn{2}{|c|}{$R^{2}$} & \multicolumn{2}{|c|}{ P-value } \\
\hline & & $\begin{array}{l}\text { Irrigation } \\
\text { season }\end{array}$ & $\begin{array}{c}\text { Non-irrigation } \\
\text { season }\end{array}$ & $\begin{array}{c}\text { Irrigation } \\
\text { season }\end{array}$ & $\begin{array}{c}\text { Non-irrigation } \\
\text { season }\end{array}$ \\
\hline Geologic subgroup & 1.4 & 0.94 & 0.92 & $\mathbf{0}$ & $\mathbf{0}$ \\
\hline Geologic subgroup & 1.3 & 0.87 & 0.89 & $\mathbf{0}$ & $\mathbf{0}$ \\
\hline Geologic subgroup & 1.2 & 0.69 & 0.60 & $\mathbf{0}$ & $\mathbf{0}$ \\
\hline Geologic subgroup & 1.1 & 0.89 & 0.90 & $\mathbf{0}$ & $\mathbf{0}$ \\
\hline \multicolumn{6}{|c|}{ Geologic subgroup, in percentage of subbasin area } \\
\hline Geologic subgroup & 3.3 & $3.00 \mathrm{E}-04$ & 4.00E-04 & 0.868 & 0.806 \\
\hline Geologic subgroup & 3.2 & 0.10 & 0.09 & 2.40E-03 & 1.00E-04 \\
\hline Geologic subgroup & 3.1 & 0.22 & 0.10 & $5.00 \mathrm{E}-06$ & 4.00E-05 \\
\hline Geologic subgroup & 2.2 & $3.00 \mathrm{E}-05$ & $1.10 \mathrm{E}-03$ & 0.958 & 0.685 \\
\hline Geologic subgroup & 2.1 & 0.08 & 0.04 & 8.90E-03 & 0.018 \\
\hline Geologic subgroup & 1.30 & $2.10 \mathrm{E}-03$ & $5.00 \mathrm{E}-06$ & 0.679 & 0.976 \\
\hline Geologic subgroup & 1.29 & 0.03 & 0.02 & 0.098 & 0.064 \\
\hline Geologic subgroup & 1.28 & $5.00 \mathrm{E}-04$ & 4.30E-03 & 0.836 & 0.419 \\
\hline Geologic subgroup & 1.27 & 4.20E-03 & $2.20 \mathrm{E}-03$ & 0.552 & 0.565 \\
\hline Geologic subgroup & 1.26 & 0.07 & 0.02 & 0.011 & 0.104 \\
\hline Geologic subgroup & 1.25 & $9.00 \mathrm{E}-04$ & $5.00 \mathrm{E}-04$ & 0.773 & 0.774 \\
\hline Geologic subgroup & 1.24 & $9.10 \mathrm{E}-03$ & 0.01 & 0.381 & 0.203 \\
\hline Geologic subgroup & 1.23 & $4.90 \mathrm{E}-03$ & 4.00E-04 & 0.520 & 0.793 \\
\hline Geologic subgroup & 1.22 & 8.00E-04 & $3.00 \mathrm{E}-05$ & 0.794 & 0.945 \\
\hline Geologic subgroup & 1.21 & $6.70 \mathrm{E}-03$ & $1.60 \mathrm{E}-03$ & 0.453 & 0.625 \\
\hline Geologic subgroup & 1.20 & $1.20 \mathrm{E}-03$ & 7.00E-04 & 0.747 & 0.740 \\
\hline Geologic subgroup & 1.19 & 0.06 & 0.10 & 0.025 & $7.00 \mathrm{E}-05$ \\
\hline Geologic subgroup & 1.18 & 0.05 & 0.04 & 0.038 & 9.50E-03 \\
\hline Geologic subgroup & 1.17 & 0.03 & 0.01 & 0.094 & 0.137 \\
\hline Geologic subgroup & 1.16 & 0.02 & $3.00 \mathrm{E}-03$ & 0.228 & 0.495 \\
\hline Geologic subgroup & 1.15 & 0.11 & 0.08 & $2.30 \mathrm{E}-03$ & 2.00E-04 \\
\hline Geologic subgroup & 1.14 & 0.09 & 0.02 & 4.40E- 03 & 0.089 \\
\hline Geologic subgroup & 1.13 & $7.50 \mathrm{E}-03$ & 0.01 & 0.429 & 0.213 \\
\hline Geologic subgroup & 1.12 & 0.01 & $1.00 \mathrm{E}-04$ & 0.264 & 0.897 \\
\hline Geologic subgroup & 1.11 & 0.06 & 0.03 & 0.024 & 0.031 \\
\hline Geologic subgroup & 1.10 & 0.18 & 0.14 & 5.00E-05 & $1.00 \mathrm{E}-06$ \\
\hline Geologic subgroup & 1.9 & 0.14 & 0.06 & 4.00E-04 & $1.40 \mathrm{E}-03$ \\
\hline Geologic subgroup & 1.7 & 0.22 & 0.16 & 4.00E-06 & 2.00E-07 \\
\hline Geologic subgroup & 1.6 & 0.06 & 0.05 & 0.025 & $5.70 \mathrm{E}-03$ \\
\hline Geologic subgroup & 1.5 & 0.35 & 0.06 & 2.00E-09 & 2.10E-03 \\
\hline Geologic subgroup & 1.4 & 0.20 & 0.11 & $1.00 \mathrm{E}-05$ & 3.00E-05 \\
\hline Geologic subgroup & 1.3 & $1.30 \mathrm{E}-03$ & 0.01 & 0.742 & 0.167 \\
\hline Geologic subgroup & 1.2 & $6.10 \mathrm{E}-03$ & $1.10 \mathrm{E}-03$ & 0.476 & 0.682 \\
\hline Geologic subgroup & 1.1 & 0.02 & 0.03 & 0.247 & 0.033 \\
\hline
\end{tabular}




\section{Appendix B. Relation between Seasonal Selenium Loads and Individual Geospatial Variables-Results of Simple Linear Regression Analysis of Seasonal Selenium Loads. - Continued}

$\left[\mathrm{R}^{2}\right.$, coefficient of determination; bold P-values indicate statistically significant values ( $\mathrm{p}$ less than 0.01$)$ and variables that were included in the multiple regression analysis]

\begin{tabular}{|c|c|c|c|c|}
\hline \multirow[b]{2}{*}{ Variable } & \multicolumn{2}{|c|}{$R^{2}$} & \multicolumn{2}{|c|}{ P-value } \\
\hline & $\begin{array}{c}\text { Irrigation } \\
\text { season }\end{array}$ & $\begin{array}{c}\text { Non-irrigation } \\
\text { season }\end{array}$ & $\begin{array}{l}\text { Irrigation } \\
\text { season }\end{array}$ & $\begin{array}{c}\text { Non-irrigation } \\
\text { season }\end{array}$ \\
\hline \multicolumn{5}{|c|}{ Agricultural crop, in percentage of subbasin area } \\
\hline Irrigated land & 0.97 & 0.97 & $\mathbf{0}$ & $\mathbf{0}$ \\
\hline Alfalfa & 0.99 & 0.96 & $\mathbf{0}$ & $\mathbf{0}$ \\
\hline Beans & 0.90 & 0.87 & $\mathbf{0}$ & $\mathbf{0}$ \\
\hline Corn & 0.98 & 0.95 & $\mathbf{0}$ & $\mathbf{0}$ \\
\hline Grapes & 0.77 & 0.60 & $\mathbf{0}$ & $\mathbf{0}$ \\
\hline Orchard & 0.95 & 0.90 & $\mathbf{0}$ & $\mathbf{0}$ \\
\hline Pasture & 0.95 & 0.96 & $\mathbf{0}$ & $\mathbf{0}$ \\
\hline Small Grain & 0.98 & 0.92 & $\mathbf{0}$ & $\mathbf{0}$ \\
\hline Sod & 0.77 & 0.66 & $\mathbf{0}$ & $\mathbf{0}$ \\
\hline Sunflowers & 0.73 & 0.63 & $\mathbf{0}$ & $\mathbf{0}$ \\
\hline Vegetables & 0.99 & 0.93 & $\mathbf{0}$ & $\mathbf{0}$ \\
\hline Wheat & 0.71 & 0.55 & $\mathbf{0}$ & $\mathbf{0}$ \\
\hline \multicolumn{5}{|c|}{ Agricultural crop, in percentage of subbasin area } \\
\hline Irrigated land & 0.05 & 0.05 & 0.049 & $6.60 \mathrm{E}-03$ \\
\hline Alfalfa & $8.10 \mathrm{E}-03$ & 0.01 & 0.411 & 0.155 \\
\hline Beans & 0.08 & $5.00 \mathrm{E}-04$ & $9.70 E-03$ & 0.776 \\
\hline Corn & $3.30 \mathrm{E}-03$ & $8.50 \mathrm{E}-03$ & 0.601 & 0.254 \\
\hline Grapes & 0.77 & 0.08 & $\mathbf{0}$ & 4.00E-04 \\
\hline Orchard & $3.30 \mathrm{E}-03$ & $2.00 \mathrm{E}-04$ & 0.602 & 0.871 \\
\hline Pasture & 0.07 & 0.05 & 0.014 & $6.80 \mathrm{E}-03$ \\
\hline Small Grains & $4.00 \mathrm{E}-04$ & $8.00 \mathrm{E}-04$ & 0.860 & 0.727 \\
\hline Sod & 0.77 & $3.00 \mathrm{E}-04$ & $\mathbf{0}$ & 0.839 \\
\hline Sunflowers & $2.40 \mathrm{E}-03$ & $2.80 \mathrm{E}-03$ & 0.653 & 0.510 \\
\hline Vegetables & $3.90 \mathrm{E}-03$ & $5.40 \mathrm{E}-03$ & 0.566 & 0.364 \\
\hline Wheat & $3.80 \mathrm{E}-03$ & $6.40 \mathrm{E}-03$ & 0.573 & 0.321 \\
\hline Irrigation water applied, in acre-feet per subbasin & 0.97 & 0.97 & $\mathbf{0}$ & $\mathbf{0}$ \\
\hline Irrigation water applied, in acre-feet per square mile of subbasin & 0.05 & 0.05 & 0.043 & $6.40 \mathrm{E}-03$ \\
\hline Irrigation channels, in acres of subbasin & 0.92 & 0.93 & $\mathbf{0}$ & $\mathbf{0}$ \\
\hline Irrigated Mancos, in acres of subbasin & 0.96 & 0.95 & $\mathbf{0}$ & $\mathbf{0}$ \\
\hline
\end{tabular}




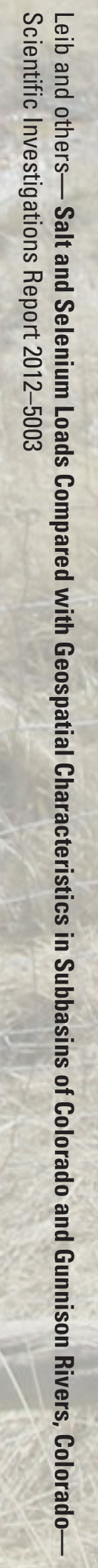

